GRADIATION\&APPLICATIONS

ISSN 2466-4294 (online) | rad-journal.org

Vol. 3 | Issue 2 | pp. 71-87, 2018

doi: 10.21175/RadJ.2018.03.013

Topical review

\title{
ANTIBACTERIAL ACTIVITY OF METALS WITH MEDICAL APPLICATION
}

\author{
Iva Slavova*, Denitsa Kiradzhiyska, Rositsa Mancheva \\ Department of Chemical Sciences, Faculty of Pharmacy, Medical University of Plovdiv, Plovdiv, Bulgaria
}

\begin{abstract}
The most common classification of certain biomaterials is proposed according to their nature, biological behavior, and application specificity. Data on the antibacterial activity of the metals $\mathrm{Ag}, \mathrm{Cu}, \mathrm{Mg}, \mathrm{Zn}, \mathrm{Se}$, and $\mathrm{Zr}$ are summarized. A brief historical review of their use in the treatment of various infections has been made. The mechanisms of antibacterial action and the role of some implant surface modifications are discussed.
\end{abstract}

Key words: Antibacterial activity, implant biomaterials, metals $\mathrm{Ag}, \mathrm{Cu}, \mathrm{Mg}, \mathrm{Zn}$, Se, and $\mathrm{Zr}$

\section{INTRODUCTION}

Diseases, injuries and traumas can cause permanent damage and degeneration of tissues in the human body. Therefore, treatment is required to recover or replace them. The growing need of artificial substitutes for tissues and bones requires the synthesis of new materials and the modification of the ones already used in medicine [1].

During the last decades, a new direction in medicine has progressively developed - implantology. Implants are medical devices whose purpose is to replace a missing or damaged biological structure and stabilize diseased parts or functions of the human body [2], [3]. Within a year, thousands of people worldwide received some kind of implant device, such as dental implants, shoulder prostheses, pacemakers, artificial hip joints, knee joint prostheses, bone fixation, joint prostheses, cardiovascular implants, eye prostheses, cochlear implants, etc. Studies have shown that, in a modern society, about $90 \%$ of the persons who are over 40 years of age suffer from degenerative and inflammatory diseases, resulting in immobility and unbearable pain [4]. The developing field of science and technology has made it possible to apply a variety of biomaterials such as implants in the human body. Implants used in orthopedics, cardiology, and dental medicine are usually placed for long periods of time. Hence, these materials must meet stringent requirements, including biocompatibility, osteoinductivity, and biomechanical compatibility with human tissues [5].

A key determinant of successful implantation is biocompatibility, i.e. the ability of the material to perform a certain function in terms of medical therapy without causing undesirable effects, including allergies and inflammation [6]. Another complicating fact is the high sensitivity of body tissues to foreign materials, which causes the stimulation of signs of poisoning and rejection [7].

In the manufacturing process of implants materials named biomaterials are used, which are characterized by specific properties [8]. A biomaterial can be defined as "any substance (other than drugs) or combination of substances of natural or artificial origin, which can be used for any period of time, as a whole or as a part of a system which treats, augments, or replaces any tissue, organ, or function of the body" [9].

Generally, biomaterials can be classified in three main groups:

1.1. Classification of biomaterials according to the function, which they perform in the human organism [10]:

$>$ orthopedic (artificial hips, knees, shoulders, wrists, intervertebral discs, fracture fixation, bone grafts);

$>$ cardiovascular (heart valves, pacemakers, catheters, graft, stents, PTCA balloons);

$>$ dental (enamels, fillings, prosthetics, orthodontics);

$>$ soft tissues (wound healing, reconstructive and augmentation, intra-ocular lens);

$>$ surgical materials (staples, sutures, scalpels, surgical tools).

1.2. According to the biological behavior, they are divided into "bioactive", "inert" and "resorbable" materials [11]:

$>$ The bioactive material elicits a specific biological response and forms bonds with tissues [12], [13];

> The inert or nearly inert material has little chemical activity, does not form any surface bonds and creates a fibrous capsule around the implant;

\footnotetext{
"islavova24@gmail.com
} 
I. Slavova et al., Antibacterial activity of metals with medical application, Rad. Applic., 2018, 3, 2, 71-87

$>$ Resorbable materials have the ability of degradation in the biological environment (the human body) [14]. The mechanism by which degradation occurs can be very diverse and ranges from dissolution through hydrolysis to corrosion [15]. This type of implant is expected to accomplish its task in the human body and progressively degrade without causing side effects thereafter. Simultaneous to the degradation of the implant, new bone tissue formation occurs at the place of the implanted material [14], [16].

\subsection{Biomaterials based on their nature [17]: \\ $>$ animal and human bone materials; \\ $>$ polymers; \\ $>$ ceramic materials; \\ $>$ metals and composites.}

The contribution of implantation to improving the quality of life and patient health is indisputable. However, the issue of avoiding implant-related infections, which may have serious consequences for the individual patient, including implant rejection, remains a great challenge to the scientific community. It should be mentioned that the rate of implant-related infections increases proportionally with the time the implant remains in the body [18]. At present, nearly 25,000 people die annually in Europe due to bacterial infections [19]. It is estimated that the most serious threat is represented by 12 bacterial strains, including Acinetobacter baumannii, Pseudomonas aeruginosa, Enterobacteriaceae, methicillin - resistant Staphylococcus aureus, better known as MRSA and others [20]. In addition, it is extremely difficult to treat these infections due to the formation (as a result of bacterial adhesion) of biofilm on the surface of the biomaterial [21]. Costerton et al. in 1999 define a bacterial biofilm as "a structural community of bacterial cells enclosed by a polymeric matrix and adherent to an inert or living surface" [22]. Moreover, biofilms are highly resistant to antibiotics. To overcome this, it is necessary to develop alternative approaches other than the conventional antibiotic therapies to prevent or reduce biofilms formation and to avoid hospital infections.

A report published by the World Health Organization (WHO) reveals that some medically important antibiotics no longer work in more than half of the infections treated in some countries. The carbapenem, used to treat people with hospitalacquired infections such as pneumonia, bloodstream infections, and infections in newborns caused by the bacteria Klebsiella pneumoniae (K. pneumoniae), is an example of the so-called "last resort" drug [23].

The increasing bacterial resistance to antibiotics requires preventive action against pathogenic microorganisms; otherwise, mankind will be exposed to various dangerous infections.

In regard to improving the biocompatibility and antibacterial properties of implants, their surface modification is increasingly gaining importance. After an extensive literature survey carried out, it is clear that the deposition of small amounts of metals such as silver $(\mathrm{Ag})$, copper $(\mathrm{Cu})$, zinc $(\mathrm{Zn})$, magnesium $(\mathrm{Mg})$, etc. on the surface of alloys is considered to be the main reason for the increased antibacterial activity [24], [25] and therefore becomes potentially applicable in medicine and medical devices. There are very limited modern reviews concerning the antibacterial activity and toxicity of metals, their basic medical applications and the mechanisms of impact. Moreover, this information is not yet systematized. Therefore, this review summarizes and analyses the latest research on this particular topic, with a special focus on the possibility of metals being used for surface modification in order to improve the antibacterial properties of medical implants and to prevent dangerous infections.

\section{ANTIBACTERIAL ACTIVITY OF SILVER}

Silver (Ag) is a non-toxic metal characterized by high antibacterial activity. It has been found that silver kills over 650 micro-organisms causing various diseases [26]. The use of silver as an effective disinfectant has been the subject of numerous studies since ancient times. It is believed that the first announcement of its antimicrobial properties was presented by the ancient Greek historian Herodotus, according to which the King of Persia drank water stored in silver vessels [27]. Silver has been widely used to treat open wounds and burns due to its antiseptic properties [28]. In the $19^{\text {th }}$ century, before the emergence of antibiotics, various types of silver salts (silver nitrate, silver sulfadiazine, silver zeolite, silver powder, silver oxide, silver chloride) were used with medical purpose for the treatment of tetanus and gonorrhea [29].

The first report about the bactericidal action of silver nitrate dates from 1884. At this time, German obstetrician Carl Credé revealed the relationship between maternal venereal disease and blindness in $79 \%$ of newborn children. He introduced $1 \% \mathrm{AgNO}_{3}$ as an eye solution to prevent ophthalmia neonatorum. The incidence rate of gonococcal conjunctivitis dropped to about $0.2 \%$ after silver nitrate was introduced [27]. Today, this method known as "Crede's prophylaxis" continues to be applied in medicine.

It should be noted that treatment with high concentrations of silver nitrate may lead to corneal injury. Also, the reduction of nitrate to nitrite can cause oxidative damage to cells, which is the primary factor of impaired re-epithelialization in the case of partial burns or donor sites [30].

Because of the widespread application of silver salts, it is a difficult task to list and comment on all possibilities for its effective application in medicine. They are effective in treating different infectious diseases, gastroenteritis, mental illness, epilepsy [31], [32]. Because of their antibacterial properties, silvercontaining materials had been successfully used to prevent the formation of bacterial biofilms on dentures and catheters [33]. The various uses of silver are complemented by the manufacture of surgical prostheses, splints, and coins [28]. In addition to a broad spectrum of antimicrobial effects, silver exhibits 
I. Slavova et al., Antibacterial activity of metals with medical application, Rad. Applic., 2018, 3, 2, 71-87

higher toxicity to microorganisms and a lower level of toxicity to mammal cells than other metals [34].

Two main theories have been proposed to explain the mechanism of antibacterial action of silver. According to the first one, the bactericidal effect is to a large extent determined by silver's affinity to react with sulfur- and phosphorus-containing compounds. Studies have revealed that metallic silver is relatively inert, but can react with both moisture on the skin surface and body fluids, resulting in the release of highly reactive silver ions $\left(\mathrm{Ag}^{+}\right)$, which are capable of binding to the bases in DNA [35]-[37]. In this way, the DNA molecule is transformed into its condensed form. It reacts with thiol (sulfhydryl) groups of proteins, which ultimately causes cell death [38], [39].

In order to clarify the antibacterial action of silver, a second mechanism is proposed in literature, which suggests that reactive oxygen groups $\left(\mathrm{ROS},{ }^{1} \mathrm{O}_{2}, \cdot \mathrm{OH}\right.$, and $\mathrm{O}_{2}{ }^{--}$) are formed in the cell membrane, which can cause irreversible damage to DNA replication affecting metabolic processes and cell division [40], [41].

A novelty in scientific literature on the mechanism of antibacterial action of silver, known as the "zombies effect", is a publication of 2015 [42]. The authors exposed pathogenic bacteria Pseudomonas aeruginosa $(P$. aeruginosa) to silver nitrate solution, at a concentration sufficient for killing the bacteria. The dead bacteria were carefully removed from the silver solution by centrifugation and filtration. It has been shown that after the addition of live $P$. aeruginosa to the already killed bacterial strains $99.999 \%$ of the live bacteria were killed. The authors explained the observed phenomenon in two main ways. On the one hand, the nanoparticles are not deactivated by killing mechanism, and therefore can carry on their biocidal effect, and on the other hand silver-killed bacteria serve as reservoirs for prolonged release of metal cations for further biocidal activity against other live bacteria.

A number of experimental results confirm the bactericidal effect of silver. Liao et al. investigate the microstructure and properties of austenitic stainless steel (AISI 304) containing a silver element (o.1, 0.2 and 0.3 wt.\%) [21]. It is well known that, along with their excellent properties such as lack of magnetism, high strength, and good corrosion resistance, austenitic steels do not possess antibacterial activity, which limits their application for biomedical purposes. The authors find that pure steel does not actually exhibit bactericidal activity but after deposition of $0.3 \mathrm{wt} . \% \mathrm{Ag}$, the samples inhibit the growth of Escherichia coli ( $E$. coli) cells.

Thus, in order to enhance osseointegration and to facilitate the interaction between bone cells and the surface of titanium implants, an effective approach is surface modification by silver plating. This method is often preferred to pure silver implants owing to the high cost of metallic silver. This motivates Das and coworkers [43] to modify Ti surface by anodization in sodium fluoride and sulfuric acid electrolytic solution. As a result, nanotubular structures with high osteoblast adhesion and good cell proliferation are formed. Additionally, six of the samples are anodized again with $0.01 \mathrm{M}$ silver nitrate solutions. Silver electrodeposited samples inhibit the growth of the bacterial strains $P$. aeruginosa, which are the major cause of hospital-acquired infections such as pneumonia, osteomyelitis, and urinary tract infections [44], [45].

A novelty in scientific literature is a number of publications in which special focus is given to the better antibacterial properties of $\mathrm{Ag}$ nanoparticles (AgNPs) compared with those of different types of silver salts and silver ions. The main advantage of these nanoparticles is that they possess a very high activity against a wide range of bacteria even at low concentrations because in these amounts $\mathrm{Ag}$ is not toxic to the human body [46]. It is also reported in scientific literature that the amount of silver nanoparticles in more than 800 consumer products is about 30\% [28]. Moreover, the advantage of nanoparticles is their smaller size, which provides larger surface-area-to-volume ratios and therefore a better contact with microorganisms for their binding to cell membranes and penetrating the bacteria [47]. Studies conducted by Martinez-Castanon et al. [48] on the behavior of $\mathrm{Ag}$ with different sizes $(7,29$, and 89 $\mathrm{nm}$ ) with respect to $E$. coli and Staphylococcus aureus ( $S$. aureus) have shown that $\mathrm{Ag}$ antibacterial activity is strongly dependent on their size. The results demonstrated that antimicrobial activity decreases with increasing particle size. The excellent bactericidal properties of silver nanoparticles might be attributed to the presence of electronic effects, which are a result of changes in the local electronic structure of surfaces of the smaller-sized particles [49].

Data on the mechanism of the inhibitory effect on microorganisms are controversial. In 2014, it was confirmed that the morphology of nanoparticles has an impact on their antibacterial effect [50]. Other authors point out that the electrostatic attraction between the negatively charged cell membrane of the microorganisms and the positive nanoparticles is an important factor related to antibacterial action of silver [51]. Kim et al. [52] also investigated the antibacterial properties of AgNPs against yeast, $E$. coli, and $S$. aureus. The results obtained by them show that Ag exhibited the weakest inhibitory effect against $S$. aureus, with a minimum inhibitory concentration (MIC) of above $33 \mathrm{nM}$. For example, the particle concentration of the solution needed to inhibit growth of yeast and $E$. coli is $6.6-13.2 \mathrm{nM}$ and $3.3-6.6 \mathrm{nM}$, respectively. In addition, there was no significant difference between the antibacterial action of silver nanoparticles and gentamicin used as control against the $S$. aureus bacteria. Some authors have proposed that the observed difference in the inhibitory effect of AgNPs relative to both types of bacteria is attributed to the broader cellular wall of the Gram-positive $S$. aureus strain compared to Gram-negative E. coli [48], [53].

In contrast, $\mathrm{Hu}$ and colleagues [54] reported that silver nanoparticles showed a better bactericidal effect against $S$. aureus and weaker activity against the $E$. coli strain than ciprofloxacin. These results indicate that Ag nanoparticles can be successfully used as antibacterial agents against ciprofloxacin-resistant bacteria. The authors explained the observed tendency with the greater affinity of the lipopolysaccharides of Gramnegative bacteria to interact with AgNPs than the 
I. Slavova et al., Antibacterial activity of metals with medical application, Rad. Applic., 2018, 3, 2, 71-87

Gram-positive cellular wall [54]-[56]. As a result, the lipopolysaccharides might trap and block the positive charges of the silver ions. On the other hand, this impedes the penetration of $\mathrm{Ag}^{+}$into the $E$. coli bacteria and hence there is a great need of extracellular silver ions for the destruction of the bacterial membrane.

Some researchers immobilized silver nanoparticles on inert supports because of the nanoparticles' tendency to agglomerate. The bactericidal effect of silver-containing compounds such as $\mathrm{AgO}, \mathrm{Ag}_{2} \mathrm{O}$, $\mathrm{Ag}_{2} \mathrm{CO}_{3}$, and $\mathrm{Ag}_{3} \mathrm{PO}_{4}$ onto different supports has been investigated in literature [57], [58]. The study of Sohrabnezhad and coworkers showed that $\mathrm{Ag}_{2} \mathrm{CO}_{3}$ supported on montmorillonite (MMT) exhibited better antibacterial activity than $\mathrm{Ag} / \mathrm{MMT}$ against $E$. coli. As mentioned above, the bactericidal action of individual materials is related to the impact of free silver ions. On the other hand, silver nanoparticles are insoluble in water so it is difficult to separate $\mathrm{Ag}^{+}$from their surface. For this reason, the authors think that the higher concentration of free silver ions obtained by contacting the sample with water is responsible for the better antibacterial activity of $\mathrm{Ag}_{2} \mathrm{CO}_{3} / \mathrm{MMT}$ [58].

Buckley and coworkers have demonstrated that nanoparticles of $\mathrm{Ag}_{3} \mathrm{PO}_{4}$ supported on hydroxyapatite (HA) with different surface areas exhibit improved antibacterial activity as compared to $\mathrm{Ag}_{2} \mathrm{CO}_{3} / \mathrm{Al}_{2} \mathrm{O}_{3}$ and unsupported $\mathrm{AgO}, \mathrm{Ag}_{2} \mathrm{O}, \mathrm{Ag}_{2} \mathrm{CO}_{3}$, and $\mathrm{Ag}_{3} \mathrm{PO}_{4}$ [57]. There is a clear trend that the bactericidal action of $\mathrm{Ag}_{3} \mathrm{PO}_{4} / \mathrm{HA}$ is increased by decreasing the concentration of Ag which is consistent with the results published in [59].

Besinis et al. compared the antibacterial activity of various nanomaterials $\left(\mathrm{Ag}, \mathrm{TiO}_{2}\right.$, and $\left.\mathrm{SiO}_{2}\right)$ to the routine disinfectant, chlorhexidine. The authors concluded that $\mathrm{Ag}$ and $\mathrm{AgNO}_{3}$ can be successfully applied to inhibit the growth of Streptococcus mutans (S. mutans) [6o], making silver-containing materials promising antibacterial agents in dentistry, where $S$. mutans is known to be the major cause of dental caries.

However, prolonged exposure to silver salts can lead to argyria, expressed in blue-gray pigmentation of the skin and mucous membranes due to the absorption of silver salts into the circulatory system and their deposition in various body tissues [61].

Despite the widespread use of silver in different fields of medicine, the data currently published on its toxicity are limited. Studies conducted by Kittler et al. [62] showed that, as a result of storage of AgNPs (in water) for up to 6 months, there was a significant increase in toxicity that the authors attributed to the release of silver ions. Chernousova et al. [63] indicate that $\mathrm{Ag}^{+}$and silver nanoparticles are toxic to eukaryotic cells at concentrations of $1-10 \mathrm{mg} / \mathrm{L}$ and $10-100 \mathrm{mg} / \mathrm{L}$, respectively.

Gliga et al. found a linear relationship between Ag nanoparticle toxicity and their size [64]. The results obtained show that only the $10-\mathrm{nm}$ particles were cytotoxic for the BEAS-2B human bronchial epithelial cells. However, there was no difference in the toxicity between the $10-\mathrm{nm}$ citrate-coated and the $10-\mathrm{nm}$ polyvinylpyrrolidone (PVP)-coated nanoparticles, indicating that their size rather than the capping agent causes nanoparticle toxicity. This trend was confirmed in the study performed by the group of $\mathrm{Li}$, who prepared Ag nanoparticles of different sizes $(25,35,45$, 60 , and $70 \mathrm{~nm}$ ), by using an optimized polyol method with PVP as a surfactant [65]. Moreover, it is found that the cytotoxicity of the tested materials against human lung fibroblast cells was increased with the decrease in particle size and concentration.

Despite the proven toxicity of silver-containing materials, their excellent antibacterial properties against a broad range of microorganisms are the cause of the continued interest of the scientific community in recent years. Evidence for the latter was obtained from a study performed by Shahverdi, the aim of which is to investigate the influence of silver nanoparticles on the antibacterial activity of some antibiotics against $S$. aureus and E. coli [66]. It has been found that the effectiveness of antibacterial action of antibiotics as penicillin G, amoxicillin, erythromycin, clindamycin, and vancomycin is increased in the presence of $\mathrm{Ag}$ nanoparticles against both bacterial strains. According to the authors, the problem with the toxicity of Ag nanoparticles can be solved by obtaining them through the reduction of the $\mathrm{Ag}^{+}$ion with the culture supernatants of $K$. pneumoniae.

In addition to the proven toxicity of silvercontaining materials, another disadvantage is that flammable and highly toxic chemicals are used to produce them by conventional methods, leading to environmental pollution. Bearing in mind that some of the chemicals or by-products left behind during the process get adsorbed on the surface of silver nanoparticles and can cause adverse effects during a medical application or treatment further purification steps are required which make the process more expensive [67].

In this regard, the interest of scientific community is focused on the development of clean, nontoxic, cost effective, and environmental-friendly methods for nanoparticles synthesis. Biological approaches using plant extracts and microorganisms have proved to be better to some physical and chemical methods due to slower kinetics, providing better control of crystal growth and the use of non-toxic chemicals, renewable materials or eco-friendly solvents [68]-[70]. Another significant advantage of the biosynthesis of nanoparticles, which is consistent with the principles of green chemistry, is that it does not require the application of conditions such as high pressure, energy and temperature [71], [72]. At present, there are many publications on the possibility that various ecological materials including plant extracts [73], [74], [68], mushrooms [75], bacteria [76], enzymes, actinomycetes [77] can transform inorganic metal ions into metal nanoparticles by the reductive capacities of the metabolites (flavonoids, terpenoids and alkaloids) present in these organisms [78]. A preferred precursor for nanoparticles synthesis are prokaryotic bacteria due to their relatively easy manipulation [79].

The advantages of the so-called "green synthesis" are confirmed by Ahmed et al. [80] that successfully use an aqueous leaf extract of the Azadirachta indica (known as the evergreen tree Neem) for bioconversion of silver ions to nanoparticles. A study on the ability of 
I. Slavova et al., Antibacterial activity of metals with medical application, Rad. Applic., 2018, 3, 2, 71-87

silver nanoparticles to inhibit the growth of two bacterial strains (E. coli and S. aureus) was performed using a disk-diffusion method. The authors find that unlike plant extract and double distilled water (as control), silver nanoparticles show good antibacterial activity that can be attributed to their larger specific surface area, providing better contact with cell wall of microorganisms [81]. In addition, the bioconversion of silver ions to nanoparticles occurs at room temperature only for 15 minutes.

Along with its inherent advantages, plant-mediated synthesis is of interest due to the existing relationship between nanoparticle shape and size of the plant product used as a reducing or capping agent. For comparison, the silver nanoparticles prepared using Neem and Carissa spinarum leaf extract have spherical and cubic shape, respectively [82]. The contribution of this publication to science is of utmost importance, as it has been shown that the antibacterial properties of silver nanoparticles depend to a large extent on their shape. Soleimani et al. [83] synthesized different shapes of silver nanostructures by varying the temperature, $\mathrm{AgNO}_{3}$ concentration, $\mathrm{pH}$ and time of synthesis. The antibacterial activity of obtained nanoparticles was investigated against the strains $S$. aureus, Bacillus subtilis, $P$. aeruginosa and $E$. coli. The results revealed that all nanoparticles inhibit the growth of the tested bacterial strains. Interestingly, Ag cubic structures exhibit the strongest inhibitory effect against bacteria, with a MIC of below $10 \mathrm{ppm}$. On the other hand, silver nanostructures with different shapes (rice, blunt-rod, sharp-rod and sphere) demonstrated antibacterial activity at concentrations above $50 \mathrm{ppm}$. Bearing in mind, that one of the basic requirements for antibacterial agents to be biocompatible with human cells, the interaction of nanoparticles with human serum albumin has been investigated. It has been found that the nanoparticles toxicity is shape and dose dependent. At $30 \mathrm{ppm}$, the cubic nanostructures completely degraded the protein, while in other shapes of nanosilver, the denaturation effect on the protein structure is not observed. As a result, the authors concluded that silver nanostructures with smooth and sharp-edged surfaces can be successfully used as antibacterial agents in the pharmaceutical industry, and to prevent the formation of biofilms in industrial instruments, respectively.

Using an aqueous powder of turmeric powder, Alsammarraie and coworkers [68] synthesized ecofriendly silver nanoparticles and investigate their antibacterial properties for two types of food pathogens (E. coli and Listeria monocytogenes). The extract contains some proteins that, according to the authors, play a key role in the stabilization of nanoparticles. It was found that AgNPs significantly inhibited both bacterial strains even at the lowest concentration of $6 \mu \mathrm{g} / \mathrm{mL}$. Good antibacterial properties of nanoparticles were also confirmed by the results of TEM and SEM analyzes showing significant shrinkage and damage of the bacterial cell wall. Based on these results, the authors conclude that this method can be successfully used to synthesize silver nanoparticles to inhibit food pathogens.

\section{ANTIBACTERIAL ACTIVITY OF COPPER}

Copper $(\mathrm{Cu})$ is an essential microelement which is necessary for human health due to the fact that it is an important component of bone, cartilage, and connective tissue. It is involved in the formation of red blood cells, iron transport, the metabolism of cholesterol and glucose, and brain development [61].

The first documented use of copper to sterilize drinking water and wounds was found 4,00o years ago in the Edwin Smith Papyrus, one of the most important medical texts of Ancient Egypt. In addition, Hippocrates (400 BC), regarded as the father of medicine, used copper to treat leg ulcers caused by varicose veins [84]. Copper has been shown to demonstrate antibacterial activity against both Gramnegative (E. coli, Salmonella enterica) and Grampositive bacterial strains (S. aureus) [61], [85], [86]. Currently, the most important advantage of copper as an antibacterial agent is its ability to inhibit the growth of MRSA. Due to bacterial resistance to various antibiotics, including beta-lactam drugs (methicillin, oxacillin, penicillin, amoxicillin, etc.), infections caused by MRSA are difficult to treat and often occur for long periods of time [87]. Mehtar et al. [88] proved the antibacterial activity of $\mathrm{Cu}$ and its alloys and they noticed that $\mathrm{Cu}$-based materials are able to inhibit the growth of MRSA, K. pneumoniae, P. aeruginosa, Candida albicans (C. albicans), Acinetobacter baumannii, and Mycobacterium tuberculosis. Temperature has a decisive role on the antibacterial properties of tested alloys. None of the alloys tested demonstrated antibacterial activity against MRSA at $4{ }^{\circ} \mathrm{C}$. On the other hand, at room temperature, C. albicans and $P$. aeruginosa were inhibited by NiAg and brass $70 / 30(\mathrm{Cu} 70 \%, \mathrm{Zn} \mathrm{30 \% )}$ at $60 \mathrm{~min}$ and 180 min while $\mathrm{Cu}$ and $\mathrm{DZR}(\mathrm{Cu} 62 \%, \mathrm{~Pb} 2.5 \%$, arsenate $0.13 \%$, Zn 22.5\%) are effective at $60 \mathrm{~min}$ and $180 \mathrm{~min}$ against $K$. pneumoniae and Acinetobacter baumannii. However, polyvinyl chloride and stainless steel used as controls showed no antimicrobial effect. The results showing that $\mathrm{Cu}$ completely inhibits $K$. pneumoniae are beneficial to medicine due to the continuous increase in the antibiotic resistance of the Gramnegative bacteria $K$. pneumoniae. They are the third most common cause of infections in the United States, characterized by high mortality rates (20-40\%) [89], [90].

The importance of copper to human health has been proven by other authors who found a relationship between bone damage and low copper levels in the human body. One of the main causes of the observed trend is that copper deficiency can lead to both changes in collagenous and non-collagenous bone matrices, as well as a reduction in insulin-like growth factor-1 (IGF1). IGF-1, also termed Somatomedin $\mathrm{C}$, which is a single-chain polypeptide hormone consisting of 70 amino acids that is secreted by human liver cells. Because IGF-1 is a major cartilage anabolic factor, its low levels can have a serious impact on health. In addition, IGF-1 can keep cartilage cells in dynamic balance in normal metabolism, but also stimulate cartilage healing [91], [18]. 
The relationship between copper concentration and insulin-like growth factor-1 levels was also confirmed by Chai and coworkers [18]. They concluded that $\mathrm{Cu}^{2+}$ released into bone stimulate the synthesis of IGF-1, which played a key role in osteogenesis. In vitro and in vivo studies revealed that stainless steel (317L) containing $4.5 \%$ of a copper alloy $(317 \mathrm{~L}-\mathrm{Cu})$ exhibits good antibacterial activity against $E$. coli and $S$. aureus together with remarkable biocompatibility when compared to $317 \mathrm{~L}$ and $\mathrm{Ti}-6 \mathrm{Al}-4 \mathrm{~V}$ controls. The lack of significant differences between preoperative and postoperative blood copper levels in rabbits makes copper alloys suitable as biomaterials.

It is also reported in scientific literature that copper has antibacterial properties against foodborne pathogens such as Salmonella enterica (S. enterica) [92]. Salmonella is the second most frequent cause of foodborne disease (11\%). Statistics indicates that Salmonella infections can lead to a fatal outcome in $28 \%$ of cases. The use of copper alloys with different $\mathrm{Cu}$ content (60-99.9\%) as an alternative to stainless steel can be an effective approach for inhibiting the bacterial growth and therefore for preventing $S$. enterica infections. Zhu et al. [92] concluded that the antibacterial activity of the alloys not only depends on the concentration of $\mathrm{Cu}$, but also on other factors. For example, a tendency towards an increase in the inhibitory effect of the alloys with the increase in the $\mathrm{Cu}$ content therein is observed. However, this regularity is not valid in all cases. Under the same conditions, higher copper concentration alloy $\mathrm{C} 75200$ $(65 \% \mathrm{Cu}, 17 \% \mathrm{Zn}, 18 \% \mathrm{Ni}$ ) exhibits a lower antibacterial effect against Salmonella than C280oo, which has a lower copper content $(60 \% \mathrm{Cu})$. The authors suggested that the observed trend was attributable to the better corrosion resistance of the $\mathrm{C} 75200$ alloy due to the presence of $\mathrm{Ni}$ (18\%). The experiments carried out by Wan et al. [93] revealed that copper ion implantation on stainless steel $317 \mathrm{~L}$ led to bacterial growth inhibition. On the other hand, weaker corrosion resistance was observed. Bearing in mind that one of the basic requirements of metal materials is high corrosion resistance, the implantation of $\mathrm{Cu}$ appears to be an ineffective approach for enhancing antibacterial properties of stainless steel.

It has been proved that $\mathrm{Cu}$ has an impact on the antibacterial activity not only of stainless steel, but also of titanium alloys. Liu and coworkers [94] reported that the $\mathrm{Cu}$ content has to be at least $5 \mathrm{wt} \%$ in order to obtain Ti-Cu alloys with stable antibacterial activity. As mentioned before, the corrosion resistance of the samples decreases with an increase in $\mathrm{Cu}$ content, necessitating the need to seek other methods to obtain materials with suitable properties. The preparation of stainless steel containing $\mathrm{Cu}$ and $\mathrm{Nb}$ may be a good approach since it has been found that even though niobium itself has no antibacterial activity, it can improve antibacterial properties of copper. In addition, the use of smaller amounts of $\mathrm{Cu}$ is ensured and negative impact on corrosion resistance can be avoided. A study on the antibacterial activity of copper(3.8\%) and niobium- (0.1\%) alloyed stainless steels, obtained by heat treatment at $550{ }^{\circ} \mathrm{C}, 700{ }^{\circ} \mathrm{C}$, and 800 ${ }^{\circ} \mathrm{C}$ for 100, 200, 300, and 400 hours [95], has shown that the most significant inhibition of $E$. coli was observed in samples treated at $700{ }^{\circ} \mathrm{C}$ and $800{ }^{\circ} \mathrm{C}$.
Although
synthetic
hydroxyapatite

$\left(\mathrm{Ca}_{10}\left(\mathrm{PO}_{4}\right)_{6}(\mathrm{OH})_{2}\right)$ does not possess any antibacterial properties, it has recently aroused great interest due to its excellent qualities such as cytocompatibility, osteoconductivity, similarity to the dentine of teeth and the inorganic part of bones and non-toxicity regardless of concentration [96]. Additionally, to provide the required osseointegration, the implants are coated by a thin layer of HA [97]. To overcome the major problem associated with the lack of antibacterial activity, Li et al. [98] synthesized $\mathrm{Cu}^{2+}{ }_{-}$and $\mathrm{Ti}^{4+}$-substituted hydroxyapatite (CuHA; TiHA) at various molar ratios $(\mathrm{M} / \mathrm{Ca}=0.01,0.05,0.10$, and 0.15$)$ by a wet chemical method coupled with an ion exchange reaction. Their results showed that the antibacterial action of $\mathrm{Cu}$ substituted hydroxyapatite against $E$. coli was more superior than that of TiHA. Regardless of the better antibacterial properties of CuHA, Ti-substituted hydroxyapatite is a preferred material for implant coatings owing to the established lower cytotoxicity to osteoblast cells.

It is interesting to study the mechanism of antibacterial action of copper nanoparticles, as the literature on this issue is scarce. Some researchers suppose that $\mathrm{Cu}$ ions released by the nanoparticles can interact with phosphorus- and sulfur-containing biomolecules such as DNA and proteins in order to destroy their structures. As a result, a disruption of biochemical processes in bacterial cells was observed [99]. Raffi and coworkers [85] stated that the antibacterial mechanism results from strong adsorption of copper ions to bacterial cells and that it depends on the nanoparticle concentration. It should be noted that $\mathrm{Cu}$ acts as a micronutrient for bacteria due to the delay of the lag phase which occurs at lower concentrations of copper. Conversely, at higher concentrations, inhibition of bacterial growth was observed.

According to the literature, bactericidal efficacy of materials is largely determined by the type of microorganisms. A comparative study on the ability of silver and copper nanoparticles to inhibit the growth of three bacterial strains (Bacillus subtilis, E. coli and $S$. aureus) was performed using a disk-diffusion method. Copper was found to demonstrate better antibacterial properties against Bacillus subtilis compared to Ag [99]. Some researchers explained the significant bactericidal effect of $\mathrm{Cu}$ nanoparticles by their greater affinity towards surface active groups of the Bacillus subtilis [100].

The antibacterial activity of $\mathrm{CuO}$ nanoparticles prepared by the thermal decomposition method was investigated against the strains $E$. coli, $S$. aureus, $P$. aeruginosa, and Bacillus circulens [101]. A significant degree of growth inhibition on $E$. coli and $S$. aureus was observed after 3 hours at a nanoparticle concentration of $4 \mathrm{mg} / \mathrm{mL}$. However, the weakest antibacterial activity of $\mathrm{CuO}$ was demonstrated against Bacillus circulens.

Despite the advantage mentioned above, the ability of copper to quickly oxidize in the air limits its application [102]. 


\section{ANTIBACTERIAL ACTIVITY OF MAGNESIUM}

Magnesium (Mg) and its alloys have gained increasing interest as materials for medical implants due to their excellent mechanical and biological properties such as strength, biodegradability, and biocompatibility. Magnesium is the fourth most abundant intracellular ion in the human body and it serves as a cofactor in more than 300 biochemical reactions, including protein synthesis, neuromuscular transmission, and muscle contraction [103], [104].

The thermodynamic instability of magnesium is considered to be the main reason for its easy oxidation in the presence of water. As a result, magnesium hydroxide $\mathrm{Mg}(\mathrm{OH})_{2}$ and hydrogen gas are formed and the $\mathrm{pH}$ of the medium is increased:

$$
\begin{aligned}
& \text { Oxidation }: \mathrm{Mg} \rightarrow \mathrm{Mg}^{2+}+2 e^{-} \\
& \text {Re duction }: 2 \mathrm{H}_{2} \mathrm{O}+2 e^{-} \rightarrow \mathrm{H}_{2(g)}+2 \mathrm{OH}^{-}
\end{aligned}
$$

In the presence of $\mathrm{Cl}$ ions in body fluids, magnesium hydroxide can transform to a soluble magnesium salt $\mathrm{MgCl}_{2}$ [105]-[107].

Magnesium-based alloys can be referred to the group of biodegradable implant materials. The similarity between mechanical properties of $\mathrm{Mg}$ containing materials and those of natural bones is a big advantage of theirs in orthopedic application. It has been proven that the specific density $\left(1.74-2 \mathrm{~g} / \mathrm{cm}^{3}\right)$ and Young's modulus (41-45 GPa) of $\mathrm{Mg}$ are comparable with those of human bones [108]. Moreover, a very rapid corrosion of $\mathrm{Mg}$ and its alloys is observed under physiological conditions ( $\mathrm{pH}$ 7.4-7.6). This prevents performing a second surgical intervention to remove the implant after bone healing [109], [110]. Another important property of $\mathrm{Mg}$ implants is the fact that free magnesium ions $\left(\mathrm{Mg}^{2+}\right)$ showed no toxic effects because the concentration of magnesium in the human body is regulated by homeostatic mechanisms [111]. In this way, the possibility of complications related to the longstanding presence of implants in the human body is excluded [109].

It has been reported [112] that implantation of an $\mathrm{Mg}$ intramedullary nail into the bone cavity of a rat inhibits the growth of $M R S A$, thereby preventing the osteomyelitis and improving new peri-implant bone formation.

The application of $\mathrm{Mg}$ as an alternative to commercially available polyurethane urethral stents is of great interest to the scientists. According to the literature, $10-50 \%$ of patients who undergo short-term catheterization develop bacterial urinary tract infections [113]. Lock et al. reported comparative investigation of the antimicrobial properties of polyurethane stents and polystyrene plates with those of magnesium strips against $E$. coli. Their results indicated that unlike $\mathrm{Mg}$, the other two substrates did not inhibit bacterial growth, as evidenced by the double density cells [106]. Authors also examined the mechanism of degradation of $\mathrm{Mg}$ in three different solutions (artificial urine, Luria Bertani broth, and deionized water) and concluded that its antibacterial action can be attributed to the greater amount of magnesium ions in the solutions due to their alkalization. In vitro studies conducted by $\mathrm{Hou}$ and coworkers [114] also confirm the significant role of the alkaline environment with respect to the antibacterial activity of high-purity $\mathrm{Mg}$ (HP $\mathrm{Mg}, 99.98$ wt.\% Mg) against MRSA. On the other hand, in vivo tests showed adhesion of a large number of bacteria on the surface of $\mathrm{Mg}$ implants and in the femur bones leading to bone infection.

In 2010 [105], it is reported that in in vitro conditions, pure magnesium metal exhibits a similar antibacterial effect against $E$. coli, $P$. aeruginosa, and $S$. aureus with that of the broad-spectrum fluoroquinolone antibiotic Enrofloxacin. At the same time, it was found that the higher $\mathrm{Mg}^{2+}$ concentration alone did not result in the inhibition of bacterial growth, but the bactericidal effect appeared to a greater extent after an increase of $\mathrm{pH}$.

Another factor that complicates the use of magnesium biomaterials is their poor corrosion resistance in a physiological environment. It is estimated that the corrosion rate of pure $\mathrm{Mg}$ (99.9\% purity) in a $3 \% \mathrm{NaCl}$ solution is about $410-8300$ mpy (milli-inch per year) [115], [116]. As a result, they lose their mechanical integrity rapidly before complete bone tissue healing. To overcome this disadvantage of magnesium samples, the alkali and thermal treatment provide a feasible alternative [117]. As already mentioned earlier, because of the absorption of the chloride ions contained in body fluids on the magnesium oxide films, it is possible that $\mathrm{Mg}(\mathrm{OH})_{2}$ interacts chemically with them to form $\mathrm{MgCl}_{2}$. In order to assess the influence of $\mathrm{Cl}^{-}$on the corrosion of the samples, simulated tissue fluids with and without chloride ions were tested. In the presence of $\mathrm{Cl}^{-}$, samples treated with a saturated solution of $\mathrm{NaHCO}_{3}$ $\mathrm{MgCO}_{3}$ corroded to a significant extent and after 10 days were completely dissolved. At the same time, the alkali-heat-treated magnesium (purity 99.9\%) samples demonstrate high corrosion resistance regardless of the composition of the body fluid.

Ren et al. [104] stated that the surface modification of pure $\mathrm{Mg}$ and the $\mathrm{AZ}_{31}$ alloy (Mg-3 wt.\% $\mathrm{Al}-1$ wt.\% $\mathrm{Zn}$ ) by fluorine and silicon-containing coatings is an effective approach to improving the antibacterial activity and reducing the degradation rate under physiological conditions. The authors reported that untreated $\mathrm{Mg}$ had great antibacterial action against both $E$. coli and $S$. aureus. The results revealed that after 6 hours the growth inhibition rates of bacteria reached over $99.9 \%$ as a result of the increase in $\mathrm{pH}$ of 7.4 to about 8.5. After 24 hours, the $\mathrm{pH}$ value increased to 10. At the same time, it has been found that a silicon-containing coating on pure $\mathrm{Mg}$ may reduce the rate of its degradation. The observed results are probably due to the smaller change in $\mathrm{pH}$ values, i.e. weaker alkalinity of the medium.

\section{ANTIBACTERIAL ACTIVITY OF ZINC}

Zinc (Zn) is an essential micronutrient involved in the construction and function of various enzymes and metalloproteins [118]. The adult human body contains about 1.5-2.5 grams of $\mathrm{Zn}$, present in all cells, organs and tissues. It is estimated that nearly $90 \%$ of the 
body's $\mathrm{Zn}$ content is stored in the skeletal muscles and bones. Zinc plays a fundamental role in the maintenance of the immune system, hormone balance, and cellular metabolism and has a positive impact on accelerating wound healing [119]. Toothpastes and mouthwashes also contain $\mathrm{Zn}$ due to its antimicrobial action. Zinc in combination with triclosan inhibits dental plaque accumulation and prevents gum inflammation (gingivitis) [120]. For this reason, Burguera-Pascu and coworkers investigate the effectiveness of mouthwash containing Zn salts (sulfate and acetate) against $S$. mutans, which is the main cause of caries [121]. Their results indicated that both of the zinc salts inhibited in equal measure the bacterial strain. In addition, the use of $\mathrm{Zn}$ salts for longer time periods does not cause the staining of oral tissues compared to other active ingredients such as $\mathrm{Ag}, \mathrm{Sn}$, or chlorhexidine.

$\mathrm{Hu}$ et al. [122] evaluated the mechanism of antibacterial action of $\mathrm{Zn}$-containing materials prepared by $\mathrm{Zn}$ incorporation into $\mathrm{TiO}_{2}$ coatings on titanium by the plasma electrolytic oxidation technique. Based on the results obtained from the ICPOES analysis showing a low concentration of free zinc ions, the authors conclude that the primary contribution to the inhibitory effect on $E$. coli and $S$. aureus is the generation of reactive oxygen radicals (ROS). At the same time, $\mathrm{Zn}$-incorporated $\mathrm{TiO}_{2}$ favors the adhesion, proliferation, and differentiation of rat bone-marrow stem cells in contrast to the $\mathrm{Zn}$-free coating and commercially pure Ti.

Despite its strong antibacterial properties, it has been found that zinc exhibits toxicity at high concentrations. Therefore, an important requirement with respect to the application of $\mathrm{Zn}$-containing materials is to obtain balance between the low cytotoxicity and the bactericidal effect. In this regard, Zhao and coworkers evaluated the effect of the $\mathrm{Zn}$ content (0.199 at.\%, 0.574 at.\%, and 1.995 at.\%) of Ti coatings on the cytoactivity of osteoblast cells (MG63) and bacteriostasis to $S$. mutans, which causes tooth plaque [123]. The authors stated that the Zn content in the coatings has to be from 0.199 at.\% to 0.574 at.\%. in order to obtain dental implants with promising features. On the other hand, a higher $\mathrm{Zn}$ content had a negative effect on cell viability.

In order to assess the effect of $\mathrm{Zn}$ on the osteogenetic function of mouse osteoblastic $\mathrm{MC}_{3} \mathrm{~T} 3-\mathrm{El}$ cells, Seo et al. [124] determined collagen concentration and bone marker protein alkaline phosphatase (ALP). The authors showed that $\mathrm{Zn}$ is favorable to bone formation as a result of an increase osteoblast cell proliferation and ALP activity and collagen synthesis in $\mathrm{MC}_{3} \mathrm{~T}_{3}-\mathrm{E}_{1}$ cells. The ability of zinc to stimulate osteogenesis is also confirmed in the study performed by the group of Kawamura [125], who implanted composite ceramics (ZnTCP/HA) consisting of $\mathrm{HA}$ and $\mathrm{Zn}$-containing $\beta$-tricalcium phosphate (ZnTCP) and ZnTCP in the femora of rabbits. Their results demonstrated the positive effect of ZnTCP/HA at a concentration of $0.316 \mathrm{Zn}$ wt.\% on bone formation, corresponding approximately to 25 times the content of $\mathrm{Zn}$ in human bones. At higher zinc content (o.633 wt.\%) in ZnTCP and ZnTCP /HA, bone resorption on the endostemal surface was observed.
In another study, Reyes-Vidal et al. [126] synthesized composite coatings of zinc/silver particles ( $\mathrm{Zn} / \mathrm{AgPs})$ by electrodeposition with cetyltrimethylammonium bromide (CTAB) as a dispersant and investigated their antimicrobial activity against $E$. coli and $S$. aureus. In the presence of $\mathrm{Zn}$ coatings without silver nanoparticles, the growth inhibition rates for $E$. coli and $S$. aureus were $87.0 \%$ and $89.5 \%$, respectively after 1 minute of contact time. On the other hand, with the same contact times and even at very low densities of the silver particles in the $\mathrm{Zn} / \mathrm{AgPs}$ coatings, the growth inhibition rates of $E$. coli and $S$. aureus increased to $94.1 \%$ and $91 \%$, respectively. The $\mathrm{Zn} / \mathrm{AgPs}$ composite coating is the preferred option owing to its ability to inhibit bacterial growth for long periods of time. For example, after 30 minutes of contact time, the growth inhibition rates of E. coli were $80.5 \%$ and $95.4 \%$ in the presence of the $\mathrm{Zn}$ coating and $\mathrm{Zn} / \mathrm{AgPs}$, respectively. After 3 months of implant insertion, a bone-to-implant contact ratio of $71 \%$ was measured for the zirconia and $83 \%$ for the titanium implants, respectively.

There is evidence that pure nano-HA and zinc doped hydroxyapatite (Zn-HA) inhibit the growth of five bacterial strains, $P$. aeruginosa, Shigella flexneri, Micrococcus luteus, S. aureus, and Bacillus cereus [127]. In another study, Iqbal et al. reported that the co-substitution of small amounts of $\mathrm{Zn}^{2+}$ and $\mathrm{Ag}^{+}$into synthetic HA structure resulted in the formation of a material with promising antibacterial properties against $S$. aureus and $E$. coli [128].

It has been shown that higher content of copper in biomaterials induces cytotoxicity effects. To overcome this, Huang et al. [129] co-substitute $\mathrm{Zn}$ as a secondary element into a CuHA coating on commercially pure titanium (Ti-cp) using the electrodeposition method. Based on the results obtained from the ICP-OES analysis showing that the released $\mathrm{Zn}$ ions increase with implantation time and similarity in the surface roughness, microstructure, and wettability of CuHA and $\mathrm{ZnCuHA}$, the authors concluded that $\mathrm{Zn}$ is the cause for the enhanced proliferation of $\mathrm{MC}_{3} \mathrm{~T}_{3}-\mathrm{E} 1$ cells. Moreover, the corrosion tests on the uncoated, HAPcoated, and ZnCuHA-coated Ti-cp show that the ZnCuHA coating demonstrates the best corrosion resistance in simulated body fluid. The in vitro cytotoxicity assays of $\mathrm{MC}_{3} \mathrm{~T} 3-\mathrm{E} 1$ osteoblast cells showed that the $\mathrm{ZnCuHA}$ coating $(\mathrm{Cu} 1.22$ wt.\% and $\mathrm{Zn}$ 1.02 wt.\%) on $\mathrm{Ti}$ promotes cell viability to a greater extent than pure HA and titanium.

\section{ANTIBACTERIAL ACTIVITY OF SELENIUM}

In the production of sulfuric acid in 1817, the Swedish chemist Berzelius proved that an unknown element was found in industrial waste. He called it selenium according to the name of the Greek goddess of the Moon (Selena) to show that as the Moon is a companion of the Earth, selenium accompanies the tellurium discovered in 1782, named after the goddess of the Earth (Telus) [130]. Selenium (Se) is an important trace element for plants, animals, and humans. In the past, it has not been used as a therapeutic agent due to its toxicity. Today, selenium is 
I. Slavova et al., Antibacterial activity of metals with medical application, Rad. Applic., 2018, 3, 2, 71-87

considered to be incorporated into 25 different selenoproteins and involved in a number of important physiological processes, which is why it is essential for the immune system to function properly [131]. The first to report the benefits of Se was the German scientist Klaus Schwarz. According to the author, the selenium contained in brewer's yeast was found to prevent liver necrosis of vitamin E-deficient rats [132], [130]. Selenium acts as a cofactor for the antioxidant enzyme glutathione peroxidase ( $\mathrm{GPx})$, the main function of which is the maintenance of low levels of hydrogen peroxide in the cells, ensuring the neutralization of free radicals, and the protection of cells from oxidative stress [133],[134].

Many studies have confirmed the role of selenium in the prevention of cancer and cardiovascular diseases. Lubinski et al. [135] reported that higher dietary selenium intake may have a positive therapeutic effect in breast cancer patients as the increased risk of death in these patients was associated with low serum selenium levels. For comparison, the survival rates were $68 \%$ and $82 \%$ for women with the lowest $(<64.4 \mu \mathrm{g} / \mathrm{L})$ and highest $(>81.0 \mu \mathrm{g} / \mathrm{L})$ levels of serum selenium, respectively. The recommended daily allowance of Se is $55 \mu \mathrm{g}$ for adults [136]. Moreover, according to a report by Combs [137], $300 \mu \mathrm{g}$ per day can reduce the risk of cancer. In 1979, it has been found that selenium deficiency can contribute to the development of Keshan disease. It mainly occurs in Sedeficient areas in China. Clinical outcomes of the disease, including multifocal myocardial necrosis, an enlarged heart, and subsequent congestive heart failure mainly affect children between 2 and 13 years of age. Another condition associated with low selenium levels in the body is endemic osteochondropathy (bone disease), called Kashin-Beck disease [138].

Despite the indisputable benefits of Se for the human body, its proper dosing is important due to the high toxicity of Se at higher concentrations. At present, the Tolerable Upper Intake Level for adults is set at $400 \mu \mathrm{g} /$ day of $\mathrm{Se}$ [139]. The chronic toxicity of selenium, known as selenosis, occurs in skin lesions, gastrointestinal disorders, and changes in keratin structure, causing hair loss and paralysis [140]. A number of studies associate these symptoms with the consumption of high-Se crops grown on soils derived from coal, containing more than $300 \mu \mathrm{g} \mathrm{Se} / \mathrm{g}$ [141].

In 2014, the positive effect of Se on the antifungal activity of $L$. plantarum and $L$. johnsonii (grown with or without selenium dioxide) against Candida albicans was confirmed [142]. According to the results, both bacterial strains alone do not inhibit the growth of $C$. albicans but are capable to reduce selenium dioxide to various sized-nanoparticles, which accumulate inside the cells and are believed to be responsible for higher antifungal activity. For instance, after $0.5 \mathrm{~h}$ of incubating $C$. albicans with Lactobacillus strains enriched with Se nanoparticles and those that are not, the viability had decreased 10 and 1000 times, respectively.

Despite the indubitable benefits of the inhibitory effect of selenium, it is important to investigate its ability to prevent the formation of bacterial biofilms with respect to its application as an antibacterial agent. Bacterial biofilms form a polymer exopolysaccharide matrix that acts as a shield to prevent the penetration of antibiotics into the biofilm and thus is a reason for ineffective treatment of bacterial infections [87].

Investigating the antibacterial properties of $\mathrm{Se}$ nanoparticles against $S$. aureus, the major cause of nosocomial infections, Tran and Webster [87] found that nanoparticles produced by the reduction of sodium selenite by glutathione inhibited bacterial growth up to 60 times compared with the control (o $\mu \mathrm{g} / \mathrm{mL} \mathrm{Se}$ ), thus preventing the formation of a bacterial biofilm. The results of the tests to determine the percentage of live bacteria in the solution showed that at Se $7.8-31 \mu \mathrm{g} / \mathrm{mL}$, only $60 \%$ of the bacteria were alive, whereas in the control they were almost $90 \%$. Wang and coworkers coated selenium nanoparticles on the surface of polycarbonate medical devices by using a precipitation method and found that obtained Se nanoparticles of 50-100 $\mathrm{nm}$ diameter can be successfully used to prevent biofilm formation by $S$. aureus [143]. In another study [144], Holinka et al. stated that the sodium selenite coating $\left(\mathrm{Na}_{2} \mathrm{SeO}_{3}\right)$ $(0.1 \%, 0.2 \%$, and $0.5 \% \mathrm{Se}$ ) on titanium discs is a suitable way to prevent implant-associated infections. It was found that selenium inhibits the growth of Staph. aureus and Staphylococcus epidermidis at MIC of $0.4 \%$. Beside their antibacterial properties, selenium coatings demonstrate excellent biocompatibility and no negative effect on the osteoblast cell adhesion (osteosarcoma cell line MG-63) on the implant surface even with $0.5 \%$ selenium.

\section{ANTIBACTERIAL ACTIVITY OF ZIRCONIUM}

The name zirconium ( $\mathrm{Zr}$ ) originates from the Arabic word Zargon meaning "golden in color" [145]. When exposed to air, zirconium quickly develops a thin protective layer of zirconium dioxide $\left(\mathrm{ZrO}_{2}\right)$, called ceramic steel. This layer prevents $\mathrm{Zr}$ from corrosion and thus prevents the release of metal ions in biological fluids [146]. $\mathrm{ZrO}_{2}$ was isolated for the first time in 1824 by Berzelius, but was actually discovered by the German chemist Martin Heinrich Klaproth 35 years earlier [147]. Zirconium dioxide can be found in nature as two minerals, Zircon $\left(\mathrm{ZrO}_{2} \mathrm{XSiO}_{2}\right)$ and Baddeleyite $\left(\mathrm{ZrO}_{2}\right)$ [148]. The unique combination of properties including mechanical strength, high durability and good chemical stability, make zirconia a promising material for the manufacture of various medical implants [149]. Helmer and Driskell were the first to report the biomedical applications of zirconium dioxide [147]. According to them, $\mathrm{ZrO}_{2}$ is a suitable alternative to titanium and aluminum dentures in hip replacement. Several references dating back to 1997 reported the zirconia abutment Zirabut $\AA$ (Wolhwend Innovative, Zurich, Switzerland) [150]. Zirconia is considered to be one of the strongest ceramics used to make implants. For example, the bending strength of $\mathrm{Al}_{2} \mathrm{O}_{3}$ (400-600 MPa) was lower than that of $\mathrm{ZrO}_{2}$ (1000 MPa) [8].

$\mathrm{ZrO}_{2}$ and $\mathrm{Ti}$ have similar properties, including biocompatibility and stability, but $\mathrm{ZrO}_{2}$ is a preferred bioactive material mainly due to its better aesthetic qualities and the fact that it creates a lower degree of phlogistic reactions in the tissue [151]. Due to the 
I. Slavova et al., Antibacterial activity of metals with medical application, Rad. Applic., 2018, 3, 2, 71-87

similarity of the color of $\mathrm{ZrO}_{2}$ to that of natural tooth structures and the possibility of preventing the unpleasant bluish staining of the gingiva that occurs with titanium implants, the application of $\mathrm{ZrO}_{2}$ is extremely important from an aesthetic point of view [152]. Significant evidence has been reported in relation to the positive effect of $\mathrm{Zr}$ on titanium alloy properties. In a study done by Ho et al. [153], it was reported that a series of binary $\mathrm{Ti}-\mathrm{Zr}$ alloys having a zirconium content ranging from 10 to 40 wt.\% had better mechanical properties than pure Ti. For example, the hardness and bending strength of Ti-40Zr were $350 \mathrm{HV}$ and $1.628 \mathrm{MPa}$, respectively, whereas those of commercially pure Ti were $186 \mathrm{HV}$ and 844 MPa.

Excellent mechanical properties of stainless steel have awakened great interest in the scientific community. This motivates Sherepo et al. [154] to assess the impact of zirconium and zirconium nitride coatings on the properties of stainless steel (316L). The authors implanted disks of chromium-nitride steel with or without titanium, zirconium, and zirconium nitride coatings in soft tissues of the back of a rat. According to their results, the uncoated implant is surrounded by a thick capsule of granulation tissue with many vessels and macrophages and neutrophil infiltration. In addition, the capsule becomes more mature with increasing implant residence time. On the other hand, 100 days after the implantation of the zirconium implant, the capsule is significantly thinner and no inflammatory process is observed. Based on the results, it may be concluded that, the zirconium coating can improve the quality of steel implants and thus make them promising biomaterials for implants used in orthopedics.

A survey of the literature has shown that there are very limited reports concerning the antibacterial activity of zirconium materials. Jangra et al. reported comparative investigation of the antimicrobial activity of $\mathrm{ZrO}_{2}$ nanoparticles and zirconium mixed ligand complexes against bacterial strains ( $E$. coli and $S$. aureus) and the fungal strain Aspergillus niger [155]. According to their findings, $\mathrm{ZrO}_{2}$ inhibits only $E$. coli, but $\mathrm{Zr}$ (IV) complexes are active against all strains tested. The antibacterial activity of $\mathrm{ZrO}_{2}$ against Gramnegative bacterium $E$. coli was confirmed by Pradhaban et al. [156]. The authors deposited $\mathrm{ZrO}_{2}$ and $\mathrm{Ag}-\mathrm{ZrO}_{2}$ composite coatings onto stainless steel (316L) by using a pulsed laser deposition method and examined the effectiveness of the resulting materials to inhibit the growth of bacterial strains $E$. coli and $S$. aureus. Based on the results obtained from the elemental analysis confirming the presence of $1.17 \mathrm{wt} . \%$ $\mathrm{Ag}$ in the $\mathrm{Ag}-\mathrm{ZrO}_{2}$ composite coatings, Pradhaban and coworkers concluded that the deposited amount of silver is enough to achieve excellent antibacterial activity against both types of bacteria. Ravikumar et al. [157] evaluated the efficacy of five types of nanoparticles $\left(\mathrm{Al}_{2} \mathrm{O}_{3}, \mathrm{Fe}_{3} \mathrm{O}_{4}, \mathrm{CeO}_{2}, \mathrm{ZrO}_{2}\right.$, and $\left.\mathrm{MgO}\right)$ on ophthalmic pathogens - namely, $K$. pneumoniae, Acinetobacter sp., P. aeruginosa, E. coli, Streptococcus pyogenes, and Streptococcus viridans. Their results demonstrated that all the nanoparticles possess antibacterial activity against $P$. aeruginosa. The minimum inhibitory concentrations of $\mathrm{ZrO}_{2}$ were 60 $\mu \mathrm{g} / \mathrm{ml}$ and $50 \mu \mathrm{g} / \mathrm{ml}$ for $P$. aeruginosa and $E$. coli, respectively. However, all tested bacterial strains were resistant to $\mathrm{CeO}_{2}$ and $\mathrm{MgO}$. In another study, Ravikumar et al. [158] showed that $\mathrm{ZrO}_{2}$ nanoparticles inhibited the growth of Salmonella $s p$. at a concentration of $2.5 \mu \mathrm{g} / \mathrm{ml}$.

One of the most important requirements for implants is their ability to form strong bonds with bone. Therefore it is necessary to study the possibilities for improving the osseointegration of zirconium implants [159]. In 2008, it was found that screw-type yttrium-stabilized zirconia implants with a modified (acid-etched) surface were integrated into the tibia of 12 minipigs in a similar way to acid-modified titanium implants [160]. After 3 months of implant insertion, a bone-to-implant contact ratio of $71 \%$ was measured for the zirconia and $83 \%$ for the titanium implants, respectively. As a result, the authors concluded that $\mathrm{ZrO}_{2}$ could be used successfully to make implants with potential application in dentistry.

Motivated by the need for high corrosion resistance of the metal implants in body fluids for long periods of time, Sanchez et al. [161] investigates whether modification of zirconium by anodisation in $\mathrm{H}_{3} \mathrm{PO}_{4}$ is an effective method for improving its surface characteristics. Results of in vivo testing of Wistar rats showed that surface modification of $\mathrm{Zr}$ favors osseointegration.

\section{CONCLUSION}

The increasing need to implant medical devices such as dental implants, hip joints, cardiovascular implants, intraocular lenses, etc., together with the increased resistance of pathogenic microorganisms to different types of antibiotics poses a serious threat to human health worldwide due to the risk from the occurrence of implant-associated infections. The latter can hardly be treated due to formation (as a result of bacterial adhesion) of biofilm on the biomaterial surface. Moreover, the rate of these infections increases proportionally with the time the implant remains in the body. For this reason, in the past decades, considerable attention has been focused on the synthesis of new materials with antibacterial properties with potential application in medicine. The deposition of small amounts of metals such as silver, copper, selenium, etc. on the surface of alloys could be considered as a suitable alternative to conventional antibiotic therapies. Therefore, this current review aimed to discuss and analyze the latest research that addressed the antimicrobial activity of metals together with their mechanism of action and the possibility of metals to be used for implant modification.

Titanium alloys, stainless steel, and synthetic hydroxyapatite with good corrosion resistance and biocompatibility are promising candidates for medical devices. A disadvantage of these materials limiting their practical application is their lack of antibacterial activity. However, there is evidence that the cosubstitution of small amounts of zinc and silver into the structure of synthetic hydroxyapatite and stainless steel resulted in the formation of materials with promising antibacterial properties. At the same time, 
I. Slavova et al., Antibacterial activity of metals with medical application, Rad. Applic., 2018, 3, 2, 71-87

Zn-incorporated $\mathrm{TiO}_{2}$ favors the adhesion, proliferation, and differentiation of rat bone-marrow stem cells in contrast to the $\mathrm{Zn}$-free coating and commercially pure Ti. Moreover, it has been reported that the surface modification of titanium implants by silver plating is an effective approach not only to improve osseointegration of implants but also to inhibit bacterial growth of $P$. aeruginosa, which is the major cause of hospital-acquired infections such as pneumonia and osteomyelitis. The excellent antibacterial properties of magnesium implants make them a suitable alternative to commercially available polyurethane urethral stents, causing bacterial urinary tract infections in $10-50 \%$ of patients.

On the other hand, it has been shown that nanoparticles exhibited superior antibacterial properties compared to antibacterial agents of the macroscopic phase. Due to their smaller size, which provides larger surface-area-to-volume ratios and therefore better contact with microorganism nanoparticles, they possess a very high activity against a wide range of bacteria even at low concentrations. Additionally, the effectiveness of the antibacterial action of antibiotics as penicillin G, amoxicillin, erythromycin, clindamycin, and vancomycin is increased in the presence of Ag nanoparticles.

Finally, it may be concluded that the modification of implants by metals with antibacterial properties is an effective approach to prevent or reduce the risk of hospital-acquired infections, which can very often lead to implant rejection, morbidity, and even mortality.

Acknowledgement: This paper has been supported by the grant No. 03/2018 (Medical University Plovdiv).

\section{REFERENCES}

1. F. J. O'Brien, "Biomaterials \& scaffolds for tissue engineering," Materials today, vol. 14, no. 3, pp. 88 - 95, Mar. 2011. DOI: 10.1016/S1369-7021(11)70058-X

2. T. Dikova, "Nano-engineered coatings on titanium implants," Scr. Sci. Medica, vol. 44, no. 2, pp. 23 - 25, Dec. 2012.

DOI: $10.14748 /$ ssm.v44i2.352

3. Y. Qin, "Textiles for implants and regenerative medicine," in Medical Textile Materials, Cambridge, UK: Elsevier, 2016, ch. 10, sec. 10.2, pp. 133 - 135 . DOI: 10.1016/C2014-0-04473-5

4. M. Geetha, A. K. Singh, R. Asokamani, and A. K. Gogia, "Ti based biomaterials, the ultimate choice for orthopaedic implants-a review," Prog. Mater. Sci., vol. 54, no. 3, pp. $397-425$, May 2009. DOI: 10.1016/j.pmatsci.2008.06.004

5. J. Venkatesan, S. K. Kim, "Chitosan composites for bone tissue engineering-an overview," Mar. Drugs, vol. 8, no. 8, pp. 2252 - 2266, Aug. 2010.

DOI: $10.3390 / \mathrm{md} 8082252$

PMid: 20948907

PMCid: PMC2953403

6. D. F. Williams, "On the mechanisms of biocompatibility," Biomaterials, vol. 29, no. 20, pp. $2941-2953$, Jul. 2008.

DOI: $10.1016 /$ j.biomaterials.2008.04.023

PMid: 18440630
7. T. M. Sridhar, S. Rajeswari, "Biomaterials corrosion," Corros. Rev., vol. 27, no. suppl, pp. 287 - 332, Jan. 2009.

DOI: $10.1515 /$ corrrev.2009.27.s1.287

8. J. Chevalier, L. Gremillard, "Ceramics for medical applications: a picture for the next 20 years," J. Eur. Ceram. Soc., vol. 29, no. 7, pp. 1245 - 1255, Apr. 2009. DOI: 10.1016/j.jeurceramsoc.2008.08.025

9. D. F. Williams, Definitions in Biomaterials: Proceedings of a Consensus Conference of the European Society for Biomaterials, Chester, UK: Elsevier, 1987.

10. E. S. Park, Biomaterials in medical devices, Medtronic, Inc., Minneapolis (MN), USA.

Retrieved from: http://insegnamento/175779-ScienzaE-Tecnologia-Dei-Biomateriali/56640-Medtronic; Retrieved on: Aug. 15, 2018

11. J. R. Jones and L. L. Hench, "Biomedical materials for new millennium: perspective on the future," Mater. Sci. Technol., vol. 17, no. 8, pp. 891-900, Jul. 2001. DOI: 10.1179/026708301101510762

12. J. R. Jones, "Scaffolds for tissue engineering" in Biomaterials, artificial organs and tissue engineering, Cambridge, UK: Elsevier, 2005, ch. 4, sec. 19, pp. $201-214$.

DOI: $10.1533 / 9781845690861.4 .201$

13. L. L. Hench, "Biomaterials: a forecast for the future," Biomaterials, vol. 19, no. 16, pp. 1419 - 1423, Aug. 1998.

DOI: $10.1016 /$ so142-9612(98)oo133-1 PMid: 9794512

14. H. Hermawan, "Biodegradable metals: state of art," in Biodegradable Metals, Heildelberg, Germany: Springer, 2012, ch. 2, pp. $13-22$. DOI: 10.1007/978-3-642-31170-3_2

15. M. Bohner, "Resorbable biomaterials as bone graft substitutes," Mater. Today, vol. 13, no. 1-2, pp. 24 - 30, Jan-Feb. 2010. DOI: 10.1016/S1369-7021(10)70014-6

16. X. N. Gu, X. H. Xie, N. Li, Y. F. Zheng, and L. Qin, "In vitro and in vivo studies on a Mg-Sr binary alloy system developed as a new kind of biodegradable metal," Acta Biomater., vol. 8, no. 6, pp. $2360-2374$, Jul. 2012. DOI: $10.1016 /$ j.actbio.2012.02.018 PMid: 22387336

17. P. Aramwit, "Introduction to biomaterials for wound healing," in Wound healing biomaterials, vol. 2, M. S. Agren, Ed., Cambridge, UK: Woodhead Publishing, 2016, ch. 1, pp. $3-38$. DOI: 10.1016/B978-1-78242-456-7.00001-5

18. H. Chai et al., "Antibacterial effect of $317 \mathrm{~L}$ stainless steel contained copper in prevention of implant-related infection in vitro and in vivo," J. Mater. Sci. Mater. Med., vol. 22, no. 11, pp. 2525 - 2535, Nov. 2011.

DOI: $10.1007 / \mathrm{s} 10856-011-4427-\mathrm{z}$ PMid: 21870079

19. Antimicrobial resistance surveillance in Europe, Annual report of the European Antimicrobial Resistance Surveillance Network (EARS-Net) 2011, European Center for Disease Prevention and Control, Stockholm, Sweden, 2012. DOI: $10.2900 / 6551$

20. Global priority list of antibiotic-resistant bacteria to guide research, discovery, and development of new antibiotics, WHO, Geneva, Switzerland, 2017.

Retrieved from:

http://www.who.int/medicines/publications/WHOPPL-Short_Summary_25Feb-ET_NM_WHO.pdf Retrieved on: Jul. 25, 2018

21. K. H. Liao, K. L. Ou, H. C. Cheng, C. T. Lin, and P. W. Peng, "Effect of silver on antibacterial properties of stainless steel," Appl. Surf. Sci., vol. 256, no. 11, pp. $3641-3645$, Mar. 2010. 
DOI: 10.1016/j.apsusc.2010.01.001

22. J. W. Costerton, P. S. Stewart, and E. P. Greenberg, "Bacterial biofilms: a common cause of persistent infections," Science, vol. 284, no. 5418, pp. 1318 - 1322, May 1999.

DOI: $10.1126 /$ science.284.5418.1318 PMid: 10334980

23. P. Stephens, "Antibiotic resistance now 'global threat', WHO warns," BBC News, Apr. 30, 2014.

Retrieved from: https://www.bbc.co.uk/news/health27204988;

Retrieved on: Aug. 5, 2018

24. P. Taylor et al., "Antibacterial properties of nine pure metals: a laboratory study using Staphylococcus aureus and Escherichia coli," Biofouling, vol. 26, no. 7, pp. $37-41$, Oct. 2010.

DOI: $10.1080 / 08927014.2010 .527000$

PMid: 20938849

25. M. Yoshinari, Y. Oda, T. Kato, and K. Okuda, "Influence of surface modifications to titanium on antibacterial activity in vitro," Biomaterials, vol. 22, no. 14, pp. 1 - 2, Jul. 2001.

DOI: 10.1016/s0142-9612(00)00392-6

PMid: 11426884

26. S. H. Jeong, Y. Y. Sang, and C. Y. Sung, "The effect of filler particle size on the antibacterial properties of compounded polymer/silver fibers," J. Mater. Sci., vol. 40, no. 20, pp. $5407-5411$, Oct. 2005. DOI: $10.1007 / \mathrm{s} 10853-005-4339-8$

27. R. L. Davies and S. F. Etris, "The development and functions of silver in water purification and disease control," Catal. Today, vol. 36, no. 1, pp. 107 - 114, Apr. 1997.

DOI: $10.1016 /$ so920-5861(96)0o203-9

28. S. W. Wijnhoven et al., "Nano-silver-a review of available data and knowledge gaps in human and environmental risk assessment," Nanotoxicology, vol. 3, no. 2, pp. 109 - 138, Jun. 2009. DOI: $10.1080 / 17435390902725914$

29. M. K. Rai, S. D. Deshmukh, A. P. Ingle, and A. K. Gade, "Silver nanoparticles: the powerful nanoweapon against multidrug-resistant bacteria," J. Appl. Microbiol., vol. 112, no. 5, pp. $841-852$, May 2012.

DOI: $10.1111 / \mathrm{j} .1365-2672.2012 .05253 . \mathrm{x}$ PMid: 22324439

30. B. S. Atiyeh, M. Costagliola, S. N. Hayek, and S. A. Dibo, "Effect of silver on burn wound infection control and healing: review of the literature," Burns, vol. 33, no. 2, pp. 139 - 148, Mar. 2007.

DOI: 10.1016/j.burns.2006.06.010 PMid: 17137719

31. M. C. Fung and D. L. Bowen, "Silver products for medical indications: risk-benefit assessment," J. Toxicol. Clin. Toxicol., vol. 34, no. 1, pp. $119-126$, Jan. 1996.

DOI: $10.3109 / 15563659609020246$ PMid: 8632503

32. M. Rai, A.P. Ingle, and S. Medici, Biomedical Applications of Metals, Basel, Switzerland: Springer International Publishing, 2018.

DOI: $10.1007 / 978-3-319-74814-6$

33. Panáček et al., "Antifungal activity of silver nanoparticles against Candida spp.," Biomaterials, vol. 30, no. 31, pp. 6333-6340, Oct. 2009.

DOI: 10.1016/j.biomaterials.2009.07.065 PMid: 19698988

34. A. E. Mohammed, "Green synthesis, antimicrobial and cytotoxic effects of silver nanoparticles mediated by Eucalyptus camaldulensis leaf extract," Asian Pac. J. Trop. Biomed., vol. 5, no. 5, pp. 382 - 386, May 2015. DOI: 10.1016/S2221-1691(15)30373-7

35. W. J. Schreurs and H. Rosenberg, "Effect of silver ions on transport and retention of phosphate by Escherichia coli," J. Bacteriol., vol. 152, no. 1, pp. 7 - 13, Oct. 1982. PMid: 6749823 PMCid: PMC221367

36. M. Rai et al., "Nanosilver: an inorganic nanoparticle with myriad potential applications," Nanotechnol. Rev., vol. 3, no. 3, pp. 281 - 309, Apr. 2014.

DOI: $10.1515 /$ ntrev-2014-0001

37. A. B. Lansdown, "Silver I: its antibacterial properties and mechanism of action," J. Wound Care, vol. 11, no. 4, pp. 125 - 130, Apr. 2002.

DOI: 10.12968/jowc.2002.11.4.26389

PMid: 11998592

38. Y. Yakabe, T. Sano, H. Ushio, and T. Yasunaga, "Kinetic studies of the interaction between silver ion and deoxyribonucleic acid," Chem. Lett., vol. 9, no. 4, pp. 373 - 376, Apr. 1980 .

DOI: $10.1246 /$ cl.1980.373

39. G. A. Fielding, M. Roy, A. Bandyopadhyay, S. Bose, "Antibacterial and biological characteristics of silver containing and strontium doped plasma sprayed hydroxyapatite coatings," Acta Biomater., vol. 8, no. 8, pp. $3144-3152$, Aug. 2012.

DOI: $10.1016 /$ j.actbio.2012.04.004

PMid: 22487928

PMCid: PMC 3393112

40. G. V. Vimbela, S. M. Ngo, C. Fraze, L. Yang, D. A. Stout, "Antibacterial properties and toxicity from metallic nanomaterials," Int. J. Nanomedicine, vol. 12 , pp. $3941-3965$, May 2017.

DOI: $10.2147 /$ IJN.S134526

PMid: 28579779

PMCid: PMC5449158

41. W. Zhang, Y. Li, J. Niu, Y. Chen, "Photogeneration of reactive oxygen species on uncoated silver, gold, nickel, and silicon nanoparticles and their antibacterial effects," Langmuir, vol. 29, no. 15, pp. $4647-4651$, Apr. 2013.

DOI: $10.1021 / \mathrm{la} 400500 \mathrm{t}$

PMid: 23544954

42. R. B. K. Wakshlak, R. Pedahzur, D. Avnir, "Antibacterial activity of silver-killed bacteria: the 'zombies' effect," Scientific reports, vol. 5, no. 9555 Apr. 2015

DOI: $10.1038 /$ srepo9555

PMid: 25906433 PMCid: PMC5386105

43. K. Das, S. Bose, A. Bandyopadhyay, B. Karandikar, B. L. Gibbins, "Surface coatings for improvement of bone cell materials and antimicrobial activities of $\mathrm{Ti}$ implants," J. Biomed. Mater. Res. Part B Appl. Biomater., vol. 87, no. 2, pp. 455 - 460, Nov. 2008. DOI: 10.1002/jbm.b.31125

PMid: 18481793

44. R. Mittal, S. Aggarwal, S. Sharma, S. Chhibber, K. Harjai, "Urinary tract infections caused by Pseudomonas aeruginosa: a minireview," J. Infect. Public Health, vol. 2, no. 3, pp. 101 - 111, 2009.

DOI: 10.1016/j.jiph.2009.08.003 PMid: 20701869

45. K. G. Kerr, A. M. Snelling, "Pseudomonas aeruginosa: a formidable and ever-present adversary," J. Hosp. Infect., vol. 73, no. 4, pp. 338 - 344, Dec. 2009.

DOI: $10.1016 /$ j.jhin.2009.04.020 PMid: $1969955^{2}$

46. B. Le Ouay and F. Stellacci, "Antibacterial activity of silver nanoparticles: a surface science insight," Nano Today, vol. 10, no. 3, pp. 339 - 354, Jun. 2015. DOI: 10.1016/j.nantod.2015.04.002

47. R. Salomoni, P. Léo, A. F. Montemor, B. G. Rinaldi, M. F. A. Rodrigues, "Antibacterial effect of silver nanoparticles in Pseudomonas aeruginosa," Nanotechnol. Sci. Appl., vol. 10, pp. 115 - 121, Jun. 2017. 
DOI: 10.2147/NSA.S133415

PMid: 28721025

PMCid: PMC5499936

48. G. A. Martinez-Castanon, N. Nino-Martinez, F. Martinez-Gutierrez, J. R. Martinez-Mendoza, F. Ruiz, "Synthesis and antibacterial activity of silver nanoparticles with different sizes," $J$. Nanoparticle Res., vol. 10, no. 8, pp. 1343 - 1348, Jul. 2008. DOI: $10.1007 / \mathrm{s} 11051-008-9428-6$

49. J. Nasrin Begam, "Biosynthesis and characterization of silver nanoparticles (AgNPs) using marine bacteria against certain human pathogens," International Journal of Advances in Scientific Research, vol. 16, no. 10, pp. 2346 - 2353, Aug. 2016.

DOI: $10.7439 /$ ijasr.v2i7.3514

5o. M. R. Nateghi, H. Hajimirzababa, "Effect of silver nanoparticles morphologies on antimicrobial properties of cotton fabrics," J. Text. Inst., vol. 105, no. 8, pp. $806-813$, Jan. 2014.

DOI: $10.1080 / 00405000.2013 .855377$

51. I. Sondi and B. Salopek-Sondi, "Silver nanoparticles as antimicrobial agent: a case study on E. coli as a model for Gram-negative bacteria," J. Colloid Interface Sci., vol. 275, no. 1, pp. 177 - 182, Jul. 2004.

DOI: $10.1016 /$ j.jcis.2004.02.012 PMid: 15158396

52. J.S. Kim et al., "Antimicrobial effects of silver nanoparticles," Nanomedicine Nanotechnology, Biol. Med., vol. 3, no. 1, pp. 95 - 101, Mar. 2007.

DOI: 10.1016/j.nano.2006.12.001 PMid: 17379174

53. J. Thiel et al., "Antibacterial properties of silver-doped titania," Small, vol. 3, no. 5, pp. 799 - 803, May 2007. DOI: $10.1002 /$ smll.200600481 PMid: 17340662

54. G. $\mathrm{Hu}$ et al., "Antibacterial activity of silver nanoparticles with different morphologies as well as their possible antibacterial mechanism," Appl. Phys. A, vol. 122, no. 10, pp. 874-880, Sep. 2016. DOI: $10.1007 /$ so0339-016-0395-y

55. S. Shrivastava et al., "Characterization of enhanced antibacterial effects of novel silver nanoparticles," Nanotechnology, vol. 18, no. 22, p. 225103, May 2007. DOI: $10.1088 / 0957-4484 / 18 / 22 / 225103$

56. H. H. Lara, N. V. Ayala-Núñez, L. D. C. I. Turrent, C. R. Padilla, "Bactericidal effect of silver nanoparticles against multidrug-resistant bacteria," World $J$. Microbiol. Biotechnol., vol. 26, no. 4, pp. 615 - 621, Oct. 2010.

DOI: 10.1007/s11274-009-0211-3

57. J. J. Buckley, A. F. Lee, and K. Wilson, "Hydroxyapatite supported antibacterial $\mathrm{Ag}_{3} \mathrm{PO}_{4}$ nanoparticles," J. Mater. Chem., vol. 20, no. 37, pp. 8056 - 8063, Oct. 2010.

DOI: $10.1039 /$ cojmo150oh

58. S. Sohrabnezhad, A. Pourahmad, M. J. M. Moghaddam, A. Sadeghi, "Study of antibacterial activity of Ag and $\mathrm{Ag}_{2} \mathrm{CO}_{3}$ nanoparticles stabilized over montmorillonite," Spectrochim. Acta Part A Mol. Biomol. Spectrosc., vol. 136, pp. 1728-1733, Feb. 2015. DOI: 10.1016/j.saa.2014.10.074 PMid: 25467663

59. J. J. Buckley, P. L. Gai, A. F. Lee, L. Olivi, K. Wilson, "Silver carbonate nanoparticles stabilised over alumina nanoneedles exhibiting potent antibacterial properties," Chem. Commun., vol. 34, pp. 4013 - 4015, Sep. 2008. DOI: $10.1039 / \mathrm{b} 809086 \mathrm{f}$ PMid: 18758610

6o. A. Besinis, T. De Peralta, R. D. Handy, "The antibacterial effects of silver, titanium dioxide and silica dioxide nanoparticles compared to the dental disinfectant chlorhexidine on Streptococcus mutans using a suite of bioassays," Nanotoxicology, vol. 8, no. 1, pp. 1 - 16, Feb. 2014.

DOI: $10.3109 / 17435390.2012 .742935$

PMid: 23092443

PMCid: PMC3878355

61. J. Liu et al., "The antibacterial properties and biocompatibility of a Ti-Cu sintered alloy for biomedical application," Biomed. Mater., vol. 9, no. 2, p. 025013, Apr. 2014.

DOI: $10.1088 / 1748-6041 / 9 / 2 / 025013$

PMid: 24565798

62. S. Kittler, C. Greulich, J. Diendorf, M. Koller, M. Epple, "Toxicity of silver nanoparticles increases during storage because of slow dissolution under release of silver ions," Chem. Mater., vol. 22, no. 16, pp. $4548-4554$, Aug. 2010.

DOI: $10.1021 / \mathrm{cm} 100023 \mathrm{p}$

63. S. Chernousova, M. Epple, "Silver as antibacterial agent: ion, nanoparticle, and metal," Angew. Chemie Int. Ed., vol. 52, no. 6, pp. 1636 - 1653, Feb. 2013.

DOI: $10.1002 /$ anie.201205923 PMid: 23255416

64. A. R. Gliga, S. Skoglund, I. O. Wallinder, B. Fadeel, H. L. Karlsson, "Size-dependent cytotoxicity of silver nanoparticles in human lung cells: the role of cellular uptake, agglomeration and Ag release," Part. Fibre Toxicol., vol. 11, no. 1, pp. 1- 17, Feb. 2014.

DOI: $10.1186 / 1743-8977-11-11$

PMid: 24529161 PMCid: PMC3933429

65. L. Li et al., "Controllable synthesis of monodispersed silver nanoparticles as standards for quantitative assessment of their cytotoxicity," Biomaterials, vol. 33 no. 6, pp. $1714-1721$, Feb. 2012.

DOI: $10.1016 /$ j.biomaterials.2011.11.030

PMid: 22137123

66. A. R. Shahverdi, A. Fakhimi, H. R. Shahverdi, S. Minaian, "Synthesis and effect of silver nanoparticles on the antibacterial activity of different antibiotics against Staphylococcus aureus and Escherichia coli," Nanomed.: Nanotechnol., Biol. Med., vol. 3, no. 2, pp. 168 - 171, Jun. 2007.

DOI: 10.1016/j.nano.2007.02.001

PMid: 17468052

67. V. Dhand et al., "Green synthesis of silver nanoparticles using Coffea arabica seed extract and its antibacterial activity," Mater. Sci. Eng. C, vol. 58, pp. $36-43$, Jan. 2016.

DOI: 10.1016/j.msec.2015.08.018 PMid: 26478284

68. F. K. Alsammarraie, W. Wang, P. Zhou, A. Mustapha, and M. Lin, "Green synthesis of silver nanoparticles using turmeric extracts and investigation of their antibacterial activities," Colloids. Surf. B. Biointerfaces., vol. 171, pp. 398 - 405, Nov. 2018. DOI: 10.1016/j.colsurfb.2018.07.059

PMid: 30071481

69. S. Husain, M. Sardar, and T. Fatma, "Screening of cyanobacterial extracts for synthesis of silver nanoparticles," World J. Microbiol. Biotechnol., vol. 31, no. 8, pp. 1279 - 1283, May 2015. DOI: $10.1007 / \mathrm{s} 11274-015-1869-3$

70. M. Ghaedi, M. Yousefinejad, M. Safarpoor, H. Z. Khafri, M. K. Purkait, "Rosmarinus officinalis leaf extract mediated green synthesis of silver nanoparticles and investigation of its antimicrobial properties," $J$. Ind. Eng. Chem., vol. 31, pp. 167 - 172, Nov. 2015. DOI: $10.1016 /$ j.jiec.2015.06.020

71. M. Soltanzadeh, M. Soltani Nejad, and G. H. S. Bonjar, "Application of Soil-borne Actinomycetes for Biological Control against Fusarium Wilt of Chickpea (Cicer arietinum) caused by Fusarium solani fsp pisi," J. Phytopath., vol. 164, no. 3, pp. 967-978, Oct. 2016. DOI: 10.1111/jph.12517 
72. A. K. Mittal, Y. Chisti, U. C. Banerjee, "Synthesis of metallic nanoparticles using plant extracts," Biotechnol. Adv., vol. 31, no. 2, pp. 346 - 356, Mar-Apr. 2013.

DOI: 10.1016/j.biotechadv.2013.01.003 PMid: 23318667

73. B. Sadeghi, F. Gholamhoseinpoor, "A study on the stability and green synthesis of silver nanoparticles using Ziziphora tenuior (Zt) extract at room temperature," Spectrochim. Acta A Mol. Biomol. Spectrosc., vol. 134, pp. 310 - 315, Jan. 2015.

DOI: 10.1016/j.saa.2014.06.046 PMid: 25022503

74. P. R. Sre, M. Reka, R. Poovazhagi, M. A. Kumar, and K. Murugesan, "Antibacterial and cytotoxic effect of biologically synthesized silver nanoparticles using aqueous root extract of Erythrina indica lam," Spectrochim. Acta A Mol. Biomol. Spectrosc., vol. 135, pp. 1137 - 1144, Jan. 2015.

DOI: 10.1016/j.saa.2014.08.019

PMid: 25189525

75. P. Sanguiñedo et al., "Extracellular biosynthesis of Silver nanoparticles using fungi and their antibacterial activity," Nano Biomed. Eng., vol. 10, no. 2, pp. 165-173, Jun. 2018.

DOI: 10.5101/nbe.v10i2.p165-173

76. E. Cremonini et al., "Biogenic selenium nanoparticles synthesized by Stenotrophomonas maltophilia Se ITE o2 loose antibacterial and antibiofilm efficacy as a result of the progressive alteration of their organic coating layer," Microb. Biotechnol., vol. 11, no. 6, pp. 1037 - 1047, Apr. 2018.

DOI: $10.1111 / 1751-7915.13260$

PMid: 29635772

PMCid: PMC6196382

77. P. Golinska et al., "Biogenic synthesis of metal nanoparticles from actinomycetes: biomedical applications and cytotoxicity," Appl. Microbiol. Biotechnol., vol. 98, no. 19, pp. 8083 - 8097, Oct. 2014. DOI: $10.1007 /$ soo253-014-5953-7 PMid: 25158833

78. P. Kuppusamy, M. M. Yusoff, G. P. Maniam, N. Govindan, "Biosynthesis of metallic nanoparticles using plant derivatives and their new avenues in pharmacological applications-An updated report," Saudi Pharmaceutical Journal, vol. 24, no. 4, pp. $473-484$, Jul. 2016 DOI: $10.1016 /$ j.jsps.2014.11.013

79. E. Abbasi et al., "Silver nanoparticles: synthesis methods, bio-applications and properties," Crit. Rev. Microbiol., vol. 42, no. 2, pp. 173 - 180, 2016. DOI: $10.3109 / 1040841$ X.2014.912200

8o. S. Ahmed, M. Ahmad, B. L. Swami, S. Ikram, "Green synthesis of silver nanoparticles using Azadirachta indica aqueous leaf extract," J. Radiat. Res. Appl. Sci., vol. 9, no. 1, pp. 1-7, Jan. 2016. DOI: $10.1016 /$ j.jrras.2015.06.006

81. H. M. Ibrahim, "Green synthesis and characterization of silver nanoparticles using banana peel extract and their antimicrobial activity against representative microorganisms," J. Radiat. Res. Appl. Sci., vol. 8, no. 3, pp. 265 - 275, Jul. 2015. DOI: 10.1016/j.jrras.2015.01.007

82. G. Benelli, "Green synthesized nanoparticles in the fight against mosquito-borne diseases and cancer-a brief review," Enzyme Microb. Technol., vol. 95, pp. 58 - 68, Dec. 2016.

DOI: 10.1016/j.enzmictec.2016.08.022 PMid: 27866627

83. F. F. Soleimani, T. Saleh, S. A. Shojaosadati, R. Poursalehi, "Green synthesis of different shapes of Silver nanostructures and evaluation of their antibacterial and cytotoxic activity," BioNanoSci., vol. 8, no. 1, pp. $72-80$, Jul. 2017.
DOI: $10.1007 / \mathrm{s} 12668-017-0423-1$

84. H. T. Michels, S. A. Wilks, J. O. Noyce, and C. W. Keevil, "Copper alloys for human infectious disease control," in Proc. Materials Science and Technology Conference (MS\&T_05), Pittsburgh (PA), 2005, pp. $1546-2498$.

Retrieved from: http://citeseerx.ist.psu.edu/viewdoc/d ownload?doi=10.1.1.559.9650\&rep=rep1\&type=pdf; Retrieved on: Aug. 15, 2018

85. M. Raffi et al., "Investigations into the antibacterial behavior of copper nanoparticles against Escherichia coli," Ann. Microbiol., vol. 60, no. 1, pp. 75 - 80, Feb. 2010.

DOI: 10.1007/s13213-010-0015-6

86. G. Faúndez, M. Troncoso, P. Navarrete, G. Figueroa, "Antimicrobial activity of copper surfaces against suspensions of Salmonella enterica and Campylobacter jejuni," BMC Microbiol., vol. 4, no. 1, p. 19, Apr. 2004.

DOI: $10.1186 / 1471-2180-4-19$

PMid: 15119960 PMCid: PMC411034

87. P. A. Tran, T. J. Webster, "Selenium nanoparticles inhibit Staphylococcus aureus growth," Int. $J$. Nanomedicine, vol. 6, pp. 1553 - 1558, Jul. 2011.

DOI: 10.2147/IJN.S21729

PMid: 21845045 PMCid: PMC 3152473

88. S. Mehtar, I. Wiid, S. D. Todorov, "The antimicrobial activity of copper and copper alloys against nosocomial pathogens and Mycobacterium tuberculosis isolated from healthcare facilities in the Western Cape: an invitro study," J. Hosp. Infect., vol. 68, no. 1, pp. 45 - 51, Jan. 2008.

DOI: $10.1016 /$ j.jhin.2007.10.009 PMid: 18069086

89. B. L. Meatherall, D. Gregson, T. Ross, J. D. Pitout, and K. B. Laupland, "Incidence, risk factors, and outcomes of Klebsiella pneumoniae bacteremia," Am. J. Med., vol. 122, no. 9, pp. 866 - 873, Sep. 2009.

DOI: 10.1016/j.amjmed.2009.03.034 PMid:19699383

90. S. S. Magill et al., "Multistate point-prevalence survey of health care-associated infections," N. Engl. J. Med., vol. 370, no. 13, pp. 1198 - 1208, Mar. 2014.

DOI: 10.1056/NEJMoa1306801

PMid: 24670166 PMCid: PMC4648343

91. K. Hirukawa et al., "Effect of tensile force on the expression of IGF-I and IGF-I receptor in the organcultured rat cranial suture," Arch. Oral Biol., vol. 50, no. 3, pp. 367 - 372, Mar. 2005.

DOI: $10.1016 /$ j.archoralbio.2004.07.003

PMid: 15740717

92. L. Zhu, J. Elguindi, C. Rensing, S. Ravishankar, "Antimicrobial activity of different copper alloy surfaces against copper resistant and sensitive Salmonella enterica," Food Microbiol., vol. 30, no. 1, pp. $303-310$, May 2012.

DOI: 10.1016/j.fm.2011.12.001 PMid: 22265316

93. Y. Z. Wan et al., "Modification of medical metals by ion implantation of copper," Appl. Surf. Sci., vol. 253, no. 24, pp. 9426 - 9429, Oct. 2007. DOI: 10.1016/j.apsusc.2007.06.031

94. J. Liu et al., "Effect of $\mathrm{Cu}$ content on the antibacterial activity of titanium - copper sintered alloys," Mater. Sci. Eng. C, vol. 35, pp. $392-400$, Feb. 2014.

DOI: $10.1016 /$ j.msec.2013.11.028 PMid: 24411393

95. M. I. Baena, M. C. Murquez, V. Matres, J. Botella, A. Ventosa, "Bactericidal activity of copper and niobium - alloyed austenitic stainless steel," Curr. Microbiol., vol. 53, no. 6, pp. 491 - 495, Dec. 2006. 
DOI: 10.1007/s00284-006-0193-4

PMid: 17072670

96. Y. Huang et al., "Antibacterial efficacy, corrosion resistance, and cytotoxicity studies of coppersubstituted carbonated hydroxyapatite coating on titanium substrate," J. Mater. Sci., vol. 50, no. 4, pp. 1688 - 1700, Nov. 2015. DOI: $10.1007 /$ s10853-014-8730-1

97. W. Chen et al., "In vitro anti-bacterial and biological properties of magnetron co-sputtered silver-containing hydroxyapatite coating," Biomaterials, vol. 27, no. 32, pp. $5512-5517$, Nov. 2006.

DOI: 10.1016/j.biomaterials.2006.07.003 PMid: 16872671

98. Y. Li, J. Ho, C. P. Ooi, "Antibacterial efficacy and cytotoxicity studies of copper (II) and titanium (IV) substituted hydroxyapatite nanoparticles," Mater. Sci. Eng. C, vol. 30, no. 8, pp. 1137 - 1144, Oct. 2010. DOI: 10.1016/j.msec.2010.06.011

99. J. P. Ruparelia, A. K. Chatterjee, S. P. Duttagupta, S. Mukherji, "Strain specificity in antimicrobial activity of silver and copper nanoparticles," Acta Biomater., vol. 4, no. 3, pp. 707 - 716, May 2008.

DOI: $10.1016 /$ j.actbio.2007.11.006 PMid: 18248860

100. T. J. Beveridge, R. G. Murray, "Sites of metal deposition in the cell wall of Bacillus subtilis," J. Bacteriol. vol. 141, no. 2, pp. 876 - 887, Feb. 1980.

PMid: 6767692

PMCid: PMC293699

101. D. Das, B. C. Nath, P. Phukon, S. K. Dolui, "Synthesis and evaluation of antioxidant and antibacterial behavior of $\mathrm{CuO}$ nanoparticles," Colloids Surfaces B Biointerfaces, vol. 101, pp. 430 - 433, Jan. 2013.

DOI: 10.1016/j.colsurfb.2012.07.002 PMid: 23010051

102. G. D. M. R. Dabera et al.,"Retarding oxidation of copper nanoparticles without electrical isolation and the size dependence of work function," Nat. Commun., vol. 8, no. 1, p. 1894, Dec. 2017

DOI: $10.1038 / \mathrm{s} 41467-017-01735-6$

PMid: 29196617

PMCid: PMC5711799

103. U. Gröber, J. Schmidt, and K. Kisters, "Magnesium in prevention and therapy," Nutrients, vol. 7, no. 9, pp. $8199-8226$, Sep. 2015.

DOI: $10.3390 /$ nu 7095388

PMid: 26404370

PMCid: PMC4586582

104. L. Ren, X. Lin, L. Tan, and K. Yang, "Effect of surface coating on antibacterial behavior of magnesium based metals," Mater. Lett., vol. 65, no. 23-24, pp. 3509 - 3511, Dec. 2011.

DOI: 10.1016/j.matlet.2011.07.109

105. D. A. Robinson, R. W. Griffith, D. Shechtman, R. B. Evans, M. G. Conzemius, "In vitro antibacterial properties of magnesium metal against Escherichia coli, Pseudomonas aeruginosa and Staphylococcus aureus," Acta Biomater., vol. 6, no. 5, pp. 1869 - 1877, May 2010.

DOI: 10.1016/j.actbio.2009.10.007 PMid: 19818422

106. J. Y. Lock et al., "Antimicrobial properties of biodegradable magnesium for next generation ureteral stent applications", in Proc. Conf. Proc. IEEE Eng. Med. Biol. Soc. 2012 (EMBC), San Diego, CA, USA, 2012 pp. $1378-1381$.

DOI: 10.1109/EMBC.2012.6346195 PMid: 23366156

107. M. Pourbaix, "Atlas of electrochemical equilibria in aqueous solutions", 2nd English Ed., Houston, Tex., USA: National Association of Corrosion Engineers, 1974.
108. M. P. Staiger, A. M. Pietak, J. Huadmai, and G. Dias, "Magnesium and its alloys as orthopedic biomaterials: a review," Biomaterials, vol. 27, no. 9, pp. 1728 - 1734, Mar. 2006.

DOI: 10.1016/j.biomaterials.2005.10.003

PMid: 16246414

109. G. He et al., "Addition of $\mathrm{Zn}$ to the ternary $\mathrm{Mg}-\mathrm{Ca}-\mathrm{Sr}$ alloys significantly improves their antibacterial property," J. Mater. Chem. B, vol. 3, no. 32, pp. $6676-6689$, Aug. 2015.

DOI: $10.1039 /$ C5TBo1319D

PMid: 26693010

PMCid: PMC4675164

110. A. H. Martinez Sanchez, B. J. C. Luthringer, F. Feyerabend, R. Willumeit, "Mg and Mg alloys: how comparable are in vitro and in vivo corrosion rates ? - A Review," ACTA Biomater., vol. 13, pp. 16 - 31, Feb. 2015.

DOI: 10.1016/j.actbio.2014.11.048

PMid: 25484334

111. D. Williams, "New interests in magnesium," Med. Device Technol., vol. 17, no. 3, pp. 9 - 10, Apr. 2006. PMid: 16736656

112. Y. Li et al., "Antibacterial properties of magnesium in vitro and in an in vivo model of implant-associated methicillin-resistant Staphylococcus aureus infection," Antimicrob. Agents Chemother., vol. 58, no. 12, pp. 7586 - 7591, Dec. 2014.

DOI: 10.1128/AAC.03936-14

PMid: 25288077 PMCid: PMC4249557

113. N. S. Morris, D. J. Stickler, and R. J. C. Mclean, "The development of bacterial biofilms on indwelling urethral catheters," World J. Urol., vol. 17, no. 6, pp. $345-350$, Dec. 1999.

DOI: $10.1007 /$ so0 3450050159

PMid: 10654364

114. P. Hou et al., "Reduced antibacterial property of metallic magnesium in vivo," Biomed. Mater., vol. 12, no. 1, p. 015010, Dec. 2016

DOI: $10.1088 / 1748-605 \mathrm{X} / 12 / 1 / 015010$ PMid: 27934788

115. P. L. Miller, B. A. Shaw, R. G. Wendt, W. C. Moshier, "Assessing the corrosion resistance of nonequilibrium magnesium-yttrium alloys," Corrosion, vol. 51, no. 12, pp. $922-931$, Dec. 1995 . DOI: $10.5006 / 1.3293568$

116. A. Feng, Y. Han, "The microstructure, mechanical and corrosion properties of calcium polyphosphate reinforced ZK60A magnesium alloy composites," J. Alloys Compd., vol. 504, no. 2, pp. 585 - 593, Aug. 2010.

DOI: 10.1016/j.jallcom.2010.06.013

117. L. Li, J. Gao, Y. Wang, "Evaluation of cyto-toxicity and corrosion behavior of alkali-heat-treated magnesium in simulated body fluid," Surf. Coatings Technol., vol. 185, no. 1, pp. $92-98$, Jul. 2004.

DOI: 10.1016/j.surfcoat.2004.01.004

118. A. S. Prasad, "Zinc: an overview," Nutrition, vol. 11, no. 1, pp. 93 - 99, Jan-Feb. 1995. PMid: 7749260

119. M. Valko, H. Morris, M. T. D. Cronin, "Metals, Toxicity and Oxidative Stress," Curr. Med. Chem., vol. 12, no. 10, pp. $1161-1208$, May 2005.

DOI: 10.2174/0929867053764635

PMid: 15892631

120. J. S. van der Hoeven, D. Cummins, M. J. M. Schaeken, and F. J.G. van der Ouderaa, "The effect of chlorhexidine and zinc/triclosan mouthrinses on the production of acids in dental plaque," Caries Res., vol. 27, no. 4, pp. 298-302, 1993.

DOI: $10.1159 / 000261554$

PMid: 8402805 
121. M. Burguera-Pascu, A. Rodríguez-Archilla, P. Baca, "Substantivity of zinc salts used as rinsing solutions and their effect on the inhibition of Streptococcus mutans," J. Trace Elem. Med. Biol., vol. 21, no. 2, pp. 92-101, Jun. 2007.

DOI: 10.1016/j.jtemb.2006.12.003 PMid: 17499148

122. H. Hu et al., "Antibacterial activity and increased bone marrow stem cell functions of $\mathrm{Zn}$-incorporated $\mathrm{TiO}_{2}$ coatings on titanium," Acta Biomater., vol. 8, no. 2, pp. $904-915$, Feb. 2012.

DOI: 10.1016/j.actbio.2011.09.031

PMid: 22023752

123. B. H. Zhao et al., "Effect of Zn content on cytoactivity and bacteriostasis of micro-arc oxidation coatings on pure titanium," Surf. Coatings Technol., vol. 228, pp. 428 - 432, Aug. 2013.

DOI: 10.1016/j.surfcoat.2012.05.037

124. H. J. Seo, Y. E. Cho, T. Kim, H. I. Shin, I. S. Kwun, "Zinc may increase bone formation through stimulating cell proliferation, alkaline phosphatase activity and collagen synthesis in osteoblastic $\mathrm{MC}_{3} \mathrm{~T} 3-\mathrm{E} 1$ cells," Nutr. Res. Pract., vol. 4, no. 5, pp. 356 - 361, Oct. 2010. DOI: $10.4162 /$ nrp.2010.4.5.356

PMid: 21103080

PMCid: PMC2981717

125. H. Kawamura et al., "Stimulatory effect of zincreleasing calcium phosphate implant on bone formation in rabbit femora," J. Biomed. Mater. Res. Part A, vol. 5o, no. 2, pp. 184 - 190, May 2000. DOI: 10.1002/(sici)1097-4636(200005)50:2<184::aidjbm13>3.0.co;2-3 PMid: 10679683

126. Y. Reyes-Vidal et al., "Electrodeposition, characterization, and antibacterial activity of zinc/silver particle composite coatings," Appl. Surf. Sci., vol. 342, pp. 34 - 41, Jul. 2015.

DOI: 10.1016/j.apsusc.2015.03.037

127. K. P. Tank, K. S. Chudasama, V. S. Thaker, M. J. Joshi, "Pure and zinc doped nano-hydroxyapatite: synthesis, characterization, antimicrobial and hemolytic studies," J. Cryst. Growth, vol. 401, pp. 474 - 479, Sep. 2014.

DOI: 10.1016/j.jcrysgro.2014.01.062

128. N. Iqbal et al., "Characterization, antibacterial and in vitro compatibility of zinc-silver doped hydroxyapatite nanoparticles prepared through microwave synthesis," Ceram. Int., vol. 40, no. 3, pp. 4507 - 4513, Apr. 2014. DOI: $10.1016 /$ j.ceramint.2013.08.125

129. Y. Huang et al., "Osteoblastic cell responses and antibacterial efficacy of $\mathrm{Cu} / \mathrm{Zn}$ co-substituted hydroxyapatite coatings on pure titanium using electrodeposition method," RSC Adv., vol. 5, no. 22, pp. 17076 - 17086, Feb. 2015. DOI: 10.1039/c4ra12118j

130. S. Kurokawa, M. J. Berry, "Selenium. Role of essential metalloid in health," in Interrelations between Essentials Metal Ions and Human Diseases, vol. 13, Dordrecht, Netherlands: Springer, 2013, pp. $499-534$. DOI: $10.1007 / 978-94-007-7500-8 \_16$

PMid: 24470102 PMCid: PMC4339817

131. C. D. Davis, P.A. Tsuji, and J.A. Milner, "Selenoproteins and cancer prevention," Annu. Rev. Nutr., vol. 32, pp. 73 - 95, Aug. 2012.

DOI: $10.1146 /$ annurev-nutr-071811-150740 PMid: 22404120

132. K. Schwarz and C. M. Foltz, "Selenium as an integral part of factor 3 against dietary necrotic liver degeneration," J. Am. Chem. Soc., vol. 79, no. 12, pp. $3292-3293$, Jun. 1957.

DOI: $10.1021 /$ jao1569a087

133. M. Navarro-Alarcon and C. Cabrera-Vique, "Selenium in food and the human body: a review," Sci. Total
Environ., vol. 400, no. 1-3, pp. 115 - 141, Aug. 2008.

DOI: 10.1016/j.scitotenv.2008.06.024

PMid: 18657851

134. C. Rodríguez-Valencia et al., "Novel selenium-doped hydroxyapatite coatings for biomedical applications," $J$. Biomed. Mater. Res. Part A, vol. 101, no. 3, pp. 853 - 861, Mar. 2013.

DOI: $10.1002 / j$ bm.a.34387 PMid: 22968925

135. J. Lubinski et al., "Serum selenium levels predict survival after breast cancer," Breast Cancer Res. Treat., vol. 167 , no. 2, pp. $591-598$, Jan. 2018

DOI: $10.1007 /$ s10549-017-4525-9

PMid: 29043463

136. P. D. Whanger, "Selenium and its relationship to cancer: an update," Br. J. Nutr., vol. 91, no. 1, pp. 11 - 28, Jan. 2004.

DOI: $10.1079 /$ bjn20031015 PMid: 14748935

137. G. F. Combs, "Selenium in global food systems," Br. $J$. Nutr., vol. 85, no. 5, pp. 517 - 547, May 2001.

DOI: $10.1079 /$ bjn2000280

PMid: 11348568

138. C. D. Thomson, "SELENIUM | Physiology," in Encyclopedia of Food Sciences and Nutrition, B. Caballero, L. C. Trugo, P. M. Finglas, Eds., 2th ed., London, UK: Academic Press, 2003, pp. 5117 - 5124. DOI: 10.1016/Bo-12-227055-X/01061-O

139. M. C. Ledesma et al., "Selenium and Vitamin E for prostate cancer: post-SELECT (Selenium and Vitamin E Cancer Prevention Trial) status," Mol. Med., vol. 7, no. 1-2, pp. 134 - 143, Jan-Feb. 2011.

DOI: 10.2119/molmed.2010.00136

PMid: 20882260

PMCid: PMC3022975

140. Environmental health criteria 58: selenium, International programme on chemical safety, WHO, Geneva, Switzerland, 1987.

Retrieved from: http://www.inchem.org/documents/eh c/ehc/ehc58.htm; Retrieved on: Jul. 18, 2018

141. G. Q. Yang, S. Z. Wang, R. H. Zhou, S. Z. Sun, "Endemic selenium intoxication of humans in China," Am. J. Clin. Nutr., vol. 37, no. 5, pp. $872-881$, May 1983.

DOI: $10.1093 / \mathrm{ajcn} / 37.5 .872$

PMid: 6846228

142. E. Kheradmand et al., "The antimicrobial effects of selenium nanoparticle-enriched probiotics and their fermented broth against Candida albicans," DARU J. Pharm. Sci., vol. 22, no. 1, pp. 1 - 6, Jun. 2014.

DOI: $10.1186 / 2008-2231-22-48$

PMid: 24906455

PMCid: PMC4060857

143. Q. Wang, T. J. Webster, "Nanostructured selenium for preventing biofilm formation on polycarbonate medical devices," J. Biomed. Mater. Res. Part A, vol. 100, no. 12, pp. 3205 - 3210, Dec. 2012.

DOI: $10.1002 / \mathrm{jbm} . \mathrm{a} \cdot 34262$ PMid: 22707390

144. J. Holinka, M. Pilz, B. Kubista, E. Presterl, R. Windhager, "Effects of selenium coating of orthopaedic implant surfaces on bacterial adherence and osteoblastic cell growth," Bone Jt. J, vol. 95, no. 5, pp. $678-682$, May 2013 .

DOI: 10.1302/0301-620X.95B5.31216

PMid: 23632681

145. S. Pilathadka, D. Vahalová, T. Vosáhlo, "The Zirconia: a new dental ceramic material. An Overview," Prague Med Rep, vol. 108, no. 1, pp. 5-12, 2007. PMid: 17682722

146. S. B. Farina, A. G. Sanchez, S. Ceré, "Effect of surface modification on the corrosion resistance of $\mathrm{Zr}-2.5 \mathrm{Nb}$ as material for permanent implants," Procedia Mater. 
I. Slavova et al., Antibacterial activity of metals with medical application, Rad. Applic., 2018, 3, 2, 71-87

Sci., vol. 8, pp. $1166-1173,2015$.

DOI: 10.1016/j.mspro.2015.04.181

147. T. Vagkopoulou, S. O. Koutayas, P. Koidis, "Zirconia in dentistry: Part 1. Discovering the nature of an upcoming bioceramic," Eur. J. Esthet. Dent., vol. 4, no. 2, 2009. PMid: 19655651

148. S. Saridag, O. Tak, G. Alniacik, "Basic properties and types of zirconia: an overview," World J. Stomatol., vol. 2, no. 3, pp. 40 - 47, Aug. 2013. DOI: 10.5321 /wjs.v2.i3.40

149. Z. Özkurt, U. İşeri, E. Kazazoğlu, "Zirconia ceramic post systems: a literature review and a case report," Dent. Mater. J., vol. 29, no. 3, pp. 233 - 245, May 2010.

DOI: $10.4012 / \mathrm{dmj} .2009-128$ PMid: 20467158

150. R. Velázquez-Cayón, C. Vaquero-Aguilar, D. TorresLagares, M. Jiménez-Melendo, J. L. Gutierrez-Perez, "Mechanical resistance of zirconium implant abutments: a review of the literature," Med. Oral Patol. Oral Cir. Bucal, vol. 17, no. 2, pp. e246 - e250, Mar. 2012.

DOI: $10.4317 /$ medoral.17462

PMid: 22143702

PMCid: PMC3448333

151. F. Carinci et al., "Effects of Emdogain on osteoblast gene expression," Oral Dis., vol. 12, no. 3, pp. 329 - 342, May 2006.

DOI: $10.1111 / \mathrm{j} .1601-0825.2005 .01204 . \mathrm{x}$ PMid: 16700745

152. A. S. Al-Radha, C. Younes, B. S. Diab, H. F. Jenkinson, "Essential oils and zirconia dental implant materials," Int. J. Oral Maxillofac. Implants, vol. 28, no. 6, pp. $1497-1505$, Nov-Dec. 2013.

DOI: $10.11607 /$ jomi.3142 PMid: 24278917

153. W. F. Ho, W. K. Chen, S. C. Wu, H. C. Hsu, "Structure, mechanical properties, and grindability of dental Ti-Zr alloys," J. Mater. Sci. Mater. Med., vol. 19, no. 10, pp. $3179-3186$, Oct. 2008.

DOI: $10.1007 / \mathrm{s} 10856-008-3454-\mathrm{x}$ PMid: 18437533

154. K. M. Sherepo, I. A. Red'ko, "Use of zirconium-based and zirconium-coated implants in traumatology and orthopedics," Biomed. Eng. (NY)., vol. 38, no. 2, pp. 77 - 79, Mar. 2004. DOI: 10.1023/b:bien.0000035726.31175.f8

155. S. L. Jangra et al., "Antimicrobial activity of zirconia (ZrO2) nanoparticles and zirconium complexes," $J$. Nanosci. Nanotechnol., vol. 12, no. 9, pp. 7105 - 7112,
Sep. 2012.

DOI: $10.1166 /$ jnn.2012.6574

PMid: 23035440

156. G. Pradhaban, G. S. Kaliaraj, V. Vishwakarma, "Antibacterial effects of silver-zirconia composite coatings using pulsed laser deposition onto 316L SS for bio implants," Prog. Biomater., vol. 3, no. 2-4, pp. $123-130$, Dec. 2014.

DOI: $10.1007 / \mathrm{s} 40204-014-0028-5$

PMid: 29470770

PMCid: PMC5301468

157. S. Ravikumar, R. Gokulakrishnan, K. Selvanathan, and S. Selvam, "Antibacterial activity of metal oxide nanoparticles against ophthalmic pathogens," Int $J$ Pharm Res Dev, vol. 3, no. 5, pp. 122 - 127, Jul. 2011. Retrieved from: https://www.researchgate.net/publicat ion/267299085 Antibacterial activity of metal oxid e nanoparticles against opthalmic pathogens? $\mathrm{sg}=2$ mhkQj4yyME1Bu4MAzVBTbEZ5nDs2u-

ufKhsu zQig9dSPHpRbwWGOKgbPmVocQ6HgmMF6 UuYp2i3PQHcdAjZMgSRgdNjNwe2g

Retrieved on: Aug. 18, 2018

158. S. Ravikumar, R. Gokulakrishnan, "The Inhibitory effect of metal oxide nanoparticles against poultry pathogens," Int. J. Pharm. Sci. Drug Res., vol. 4, no. 2, pp. 157 - 159, Apr-Jun. 2012.

Retrieved from: http://oaji.net/articles/2014/3641401976498.pdf Retrieved on: Aug. 11, 2018

159. Z. Özkurt and E. Kazazoğlu, "Zirconia dental implants: a literature review," J. Oral Implantol., vol. 37, no. 3, pp. 367-376, Jun. 2011.

DOI: 10.1563/AAID-JOI-D-09-00079

PMid: 20545529

160. R. Depprich et al., "Osseointegration of zirconia implants compared with titanium: an in vivo study," Head Face Med., vol. 4, no. 1, p. 30, Dec. 2008.

DOI: $10.1186 / 1746-160 X-4-30$

PMid: 19077228

PMCid: PMC2614983

161. G. Sanchez, J. Ballarre, J. C. Orellano, G. Duffó, S. Cere, "Surface modification of zirconium by anodisation as material for permanent implants: in vitro and in vivo study," J. Mater. Sci. Mater. Med., vol. 24, no. 1, pp. $161-169$, Jan. 2013.

DOI: $10.1007 / \mathrm{s} 10856-012-4770-8$

PMid: 23053800 